Algal Research

July 2017, Volume 25 Pages 207-215

http://dx.doi.org/10.1016/j.algal.2017.04.034

http://archimer.ifremer.fr/doc/00390/50127/

(C) 2017 Elsevier B.V. All rights reserved.

\title{
Antimelanoma activity of Heterocapsa triquetra pigments
}

\author{
Haguet Quentin ${ }^{1}$, Bonnet Antoine ${ }^{1,2}$, Bérard Jean-Baptiste ${ }^{3}$, Goldberg Joelle ${ }^{1}$, Joguet Nicolas ${ }^{4}$, \\ Fleury Audrey ${ }^{1}$, Thiéry Valérie ${ }^{1}$, Picot Laurent ${ }^{1,{ }^{*}}$
}

${ }^{1}$ UMRi CNRS 7266 LIENSs, University of La Rochelle, 17042 La Rochelle, France

${ }^{2}$ Plateforme d'analyse haute résolution des biomolécules, Université de La Rochelle, UMRi CNRS 7266

LIENSs, 17042 La Rochelle, France

${ }^{3}$ IFREMER, Laboratoire BRM/PBA, Rue de I'lle d'Yeu, 44311 Nantes, France

${ }^{4}$ IDCAPS, filiale R\&D INNOV'IA, 4 rue Samuel Champlain, Z.I. Chef de Baie, 17000 La Rochelle,

France

* Corresponding author : Laurent Picot, email address : laurent.picot@univ-Ir.fr

\begin{abstract}
:
Heterocapsa triquetra $(H t)$, a non-toxic dinophyte, was selected to investigate the presence of pigments inhibiting melanoma cells growth. We developed an innovative microwave-assisted extraction process (MAE), determined the $\mathrm{Ht}$ pigment composition using Reverse Phase-High Performance Liquid Chromatography (HPLC) and high-resolution Ultra Performance Liquid Chromatography-Mass Spectrometry ${ }^{\mathrm{E}}$ (UPLC-MS ${ }^{\mathrm{E}}$ ) analysis and assessed their antiproliferative activity in human invasive melanoma cells (A2058) grown in vitro. MAE allowed a fast and efficient extraction of $H$ t pigments as compared with conventional processes (soaking, sonication). Seventeen pigments and derivatives were unequivocally identified by UPLC-MSE in the Ht extract, among which two were supposed to be produced during the extraction (hydroxylated chlorophyll $a$ and pheophytin a). Pigment composition was fully coherent with that usually described for the DINO-1 peridiniales order. It included the uncommon carotenoids P457, peridininol, peridinin, pyrrhoxanthin, diadinochrome and diadinoxanthin. Ht pigment ethanol extract induced 18\% growth inhibition of A2058 malignant melanoma cell line after a $72 \mathrm{~h}$ treatment at $100 \mathrm{\mu g} \cdot \mathrm{mL}^{-1}$ and pigment purification confirmed the highly significant antiproliferative activity of chlorophyll $c 2$, peridinin, dinoxanthin and diatoxanthin on this cell line. Our data demonstrate for the first time the effectiveness of microwave irradiation to extract pigments from dinophytes. They also indicate that Heterocapsa triquetra and other dinophytes are interesting sources to purify bioactive pigments with antiproliferative activities in chemoresistant melanoma cells. These results strongly support previous findings about the anticancer activity of phytoplankton pigments and reinforce the possible interest of these molecules as natural cytostatic drugs.
\end{abstract}




\section{Graphical abstract}

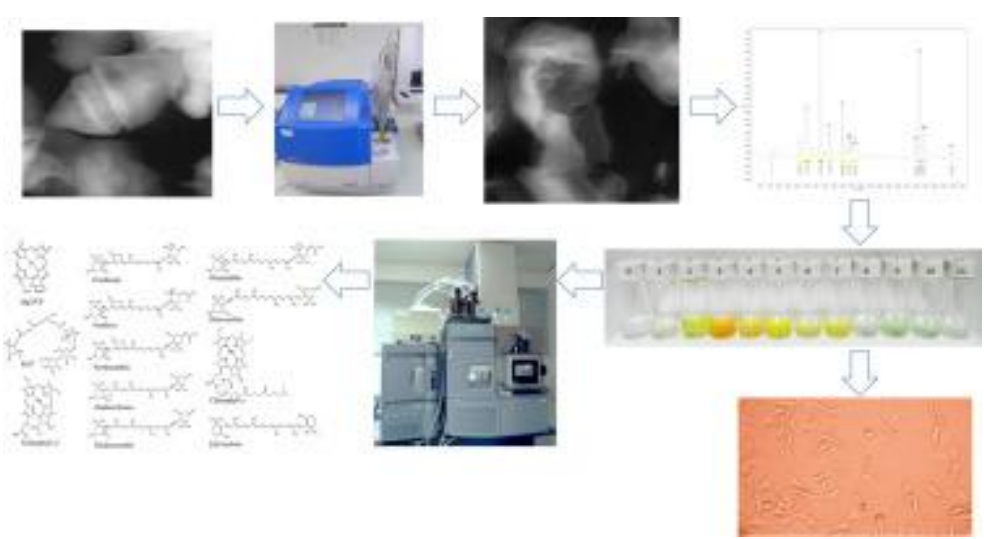

\section{Highlights}

Microwave-assisted extraction was performed for the first time to extract pigments from a dinophyte (Heterocapsa triquetra). MAE allowed a fast and non-degradative extraction of $\mathrm{Ht}$ pigments. The pigment composition of Heterocapsa triquetra was studied using high resolution UPLC-MS ${ }^{E}$ and included uncommon chlorophylls and carotenoids - Chlorophyll $c 2$, peridinin, dinoxanthin and diatoxanthin exerted antiproliferative activity in A2058 human melanoma cells. Heterocapsa triquetra and other dinophytes as interesting sources to purify pigments exerting antimelanoma activities.

Keywords : Dinophyte, Heterocapsa, Melanoma, Microalgae, Microwave assisted extraction, Pigment 


\section{Introduction}

Melanoma accounts for less than one percent of skin cancer cases, but is responsible for the vast majority of skin cancer deaths [1]. About 132,000 new cases are diagnosed worldwide each year and the only efficient cure is the early chirurgical resection of the primary tumor, before the spread of cancer cells to nearby lymph nodes [2]. Advanced and metastatic melanoma (grade III and IV) have very poor prognosis as most chemotherapeutical agents are ineffective in killing melanoma cells, which are constitutively or adaptively resistant to anticancer drugs [3]. Additionally, melanoma cells are highly resistant to radiotherapy $[2,4]$. Although major progress has come from the development of therapies targeting cells with specific mutations within the patient's tumor [4,5], there is still an urgent need for improved and second-line treatments because of the rapid acquisition of drug resistance. Natural products are thus extensively explored to discover cytostatic drugs that could be used in combination with targeted chemotherapy and immunotherapy to limit the growth of chemoresistant melanoma cells [6-9]. Particularly, plant and algae carotenoids have shown a great potential as they exert cytotoxic, cytostatic, antimetastatic, anti-inflammatory and antiangiogenic activities [10-14]. Moreover, they were shown to reverse cancer cell multidrug resistance to pro-apoptotic drugs by inhibiting efflux systems $[15,16]$. It was demonstrated that fucoxanthin, the most studied algal carotenoid, inhibits the growth of melanoma cell lines in vitro and limits melanoma tumor growth in vivo [12,17]. It also limits melanoma metastasis in murine models, suggesting a possible clinical interest to slow the progression of melanoma in humans [18]. Zeaxanthin and $\beta$-cryptoxanthin, two carotenoids abundant in microalgae, were found to inhibit the growth of highly invasive human melanoma cells resistant to chemotherapy in vitro and induce apoptosis in uveal melanoma cells [19-21]. Contrary to highly selective anticancer drugs, carotenoids have no oral toxicity [22] and act as pleiotropic perturbators of signaling pathways regulating cancer cell survival, invasivity and 
tumor angiogenesis [23]. While several investigations have been published about the biological activity of abundant carotenoids, there is still limited information about the cytotoxicity of minor carotenoids, present in low abundance in original phytoplankton species. In this view, we selected a non-toxic dinophyte, Heterocapsa triquetra $(H t)$, developed an optimized microwave-assisted pigment extraction process, defined $\mathrm{Ht}$ pigment composition using a high-resolution UPLC-MS ${ }^{\mathrm{E}}$ analysis, and assessed the cytotoxic activity of $H t$ pigments in the A2058 invasive melanoma cell line.

\section{Material and methods}

\subsection{Microalgae}

Heterocapsa triquetra $(\mathrm{Ht})$ is a marine phytoplankton species that belongs to the Dinophyceae class, Peridiniales order (peridinin-containing dinophytes). It is abundant in low salinity temperate coastal waters and causes extensive blooms during summer [24]. Ht cells are 16-30 $\mu \mathrm{m}$ long and 9-18 $\mu \mathrm{m}$ wide. The characteristic feature of $H t$ is the presence of a thick cellulosic theca consisting of a conical epitheca with straight sides and a rounded end associated to a hypotheca exhibiting an assymetrical horn and a unique protusion [24]. Cells have no spines and the species was named according to the presence of three acute angles in the structure of the cell wall. [24]. $H t$ was chosen as a relevant model to perform the microwave-assisted extraction of pigments as its thick cellulosic armour constitutes a hard mechanical barrier limiting access to intracellular metabolites using soft processes $[25,26]$. Moreover, the cytotoxicity of several $\mathrm{Ht}$ pigments was unstudied in human cancer cells. 


\subsection{Microalgae culture, harvest and freeze-drying}

$H t$ (HT99PZ strain) was cultivated in batch mode in 10L carboy containing L1 medium enriched seawater [27]. Continuous irradiance was set at $120 \mu \mathrm{mol} \cdot \mathrm{m}^{-2} \cdot \mathrm{s}^{-1}$ and temperature at $20^{\circ} \mathrm{C} . H t$ cells were harvested at the beginning of the stationary phase and concentrated using centrifugation $\left(4000 \mathrm{~g}, 4^{\circ} \mathrm{C}, 20 \mathrm{mn}\right)$. Pellet was stored at $-80^{\circ} \mathrm{C}$ and freeze-dried at $-55^{\circ} \mathrm{C}$ and $\mathrm{P}<1 \mathrm{hPa}$, in a freeze-dryer equipped with a HetoLyoPro 3000 condenser and a Heto cooling trap (Thermo, France).

\subsection{Microwave-assisted extraction of $\mathrm{Ht}$ pigments}

Because of its hard cell wall that limits intracellular metabolites extractability, we optimized a microwave-assisted extraction (MAE) to obtain high pigments extraction yields using a fast process, as previously reported by our group [28,29]. Twenty mg freeze-dried $H t$ cells were suspended in $5 \mathrm{~mL}$ ethanol in $10 \mathrm{~mL}$ sealed glass vials under air. The cell suspension was stirred at $780 \mathrm{rpm}$ by means of an adjustable rotating magnetic plate located below the floor of the microwave cavity and a Teflon-coated magnetic stir bar inside the vessel. It was irradiated at $50^{\circ} \mathrm{C}$ for 5 min with a ramp period of $40 \mathrm{~s}$ until temperature was reached, in a Biotage Initiator microwave reactor $(400 \mathrm{~W}$, monomode system with a microwave power delivery system ranging from 5 to $400 \mathrm{~W}$ ). Reaction temperature, power input and pressure were computer controlled and determined using the built-in, on-line IR and pressure sensors. The software algorithm regulated the microwave output power so that the selected maximum temperature was maintained for the desired reaction irradiation time. After the irradiation period, the reaction vessel was cooled rapidly to ambient temperature by compressed air (gasjet cooling). The extract was centrifuged at $4500 \mathrm{~g}$ for $10 \mathrm{~min}$ at $20{ }^{\circ} \mathrm{C}$ and the supernatant containing pigments was evaporated to dryness using a rotavapor. To validate that MAE extraction allowed a complete pigment extraction, we compared the color of the MAE extract 
and remaining biomass to those obtained after 30 min soaking in ethanol at $50^{\circ} \mathrm{C}$ or sonication $5 \mathrm{~min}$ at $50 \mathrm{~W}-30 \mathrm{kHz}$ (UP50H ultrasonicator, Hielscher Ultrasonics $\mathrm{GmbH}$, Germany).

\subsection{Scanning electron microscopy (SEM)}

To confirm cell rupture during MAE, $H t$ cells were freeze-dried before or after MAE, placed on a conductive double layer carbon support and examined by SEM using a Philips-FEI Quanta 200 ESEM/FEG microscope (environmental mode) equipped with a FEG canon delivering 1 to $30 \mathrm{KV}$ beam current.

\subsection{Collection of $\boldsymbol{H t}$ pigments for structural analysis and cell culture studies}

$H t$ pigments contained in the ethanolic extract were separated and collected using RP-HPLC in semi-preparative conditions. The RP-HPLC system was composed of a binary pump (Waters, W600), an autosampler (Waters, W717), a thermostated $\left(20^{\circ} \mathrm{C}\right)$ column compartment, and a photodiode-array detector (Waters, W486). The column used was a semipreparative Phenomenex Luna C18 (2) $(250 \times 10 \mathrm{~mm}, 10 \mu \mathrm{m})$. Flow rate was fixed at 5 $\mathrm{mL} \cdot \mathrm{min}^{-1}$ and the mobile phase consisted of a ternary gradient of solvent A (Methanol/water (80/20)); solvent B (Acetonitrile/water (90/10)) and solvent C (Ethyl acetate). The gradient flow program was the same as previously reported in our publications: $0 \mathrm{~min}, 100 \% \mathrm{~A} ; 3 \mathrm{~min}$, $100 \% \mathrm{~B} ; 35 \mathrm{~min}, 30 \% \mathrm{~B}$ and $70 \% \mathrm{C} ; 38 \mathrm{~min}, 100 \% \mathrm{C} ; 41 \mathrm{~min}, 100 \% \mathrm{C}$; $43 \mathrm{~min}, 100 \% \mathrm{~B} ; 45 \mathrm{~min}, 100 \%$ A. Elution was monitored at $435 \mathrm{~nm}$. 


\subsection{UPLC-MS ${ }^{\mathrm{E}}$ analysis of $\mathrm{Ht}$ pigments purified by RP-HPLC}

The pigment composition of $H t$ RP-HPLC fractions was determined by high resolution $\mathrm{UPLC}_{\mathrm{M}} \mathrm{S}^{\mathrm{E}}$ analysis, as previously described by our group [30]. UPLC-MS ${ }^{\mathrm{E}}$ is a relatively new technique based on the quasi-simultaneous detection of parent and fragments ions obtained after UPLC separation of metabolites and ionization in low- and high-energy collision modes alternating at medium frequency (about $30 \mathrm{~Hz}$ ). All molecules ionizing at low collision energy are detected and identified as parent ions. A few milliseconds afterward, switching to the high-energy collision mode induces the fragmentation of parent ions, and the quasi-simultaneous detection of fragment ions. As a consequence, a complex mix of metabolites can be analyzed in a single run, no precursor ion is selected for individual fragmentation and fragment ions can be related to their precursors using a mass fragmentation software and high-resolution mass databanks. This technique was already applied with success in various metabolomic and proteomic studies [31-35] including the identification of major carotenoids and chlorophylls in Dunaliella salina [30] and Porphyridium purpureum [30]. For the UPLC-MS ${ }^{\mathrm{E}}$ analysis of $H t$ pigments, parent and fragment ions with high resolution $\mathrm{m} / \mathrm{z}$ were compared to our $\mathrm{MS}^{\mathrm{E}}$ pigment database, completed with the commercially available standard dinophytes pigments.

\subsubsection{Equipment and analytical conditions}

UPLC-MS $^{\mathrm{E}}$ analyses were performed using an Acquity UPLC H-Class (Waters, Milford, Massachussets, USA) coupled to a Xevo G2 S Q-TOF (Waters, Manchester, United Kingdom) mass spectrometer equipped with an electrospray ionization (ESI) source (Waters, Manchester, United Kingdom). The chromatographic system consisted of a quaternary pump (Quaternary Solvent Manager, Waters) and an autosampler (Sample Manager-FTN, Waters) 
equipped with a $10 \mu \mathrm{L}$ sample loop. The $H t$ ethanol extract was hundredth diluted in methanol and five microliters of methanolic solutions were injected into a Waters Acquity UPLC BEH C18 column $(2.1 \times 50 \mathrm{~mm}, 1.7 \mu \mathrm{m})$. The system was operated under the following gradient elution program: solution $\mathrm{A}\left(0.01 \%\right.$ formic acid in $\left.\mathrm{H}_{2} \mathrm{O}\right)$ in solution $\mathrm{B}(0.01 \%$ formic acid in $\mathrm{MeOH})$ at a flow rate of $400 \mu \mathrm{L} \cdot \mathrm{min}^{-1}$ as follows: $0-0.5 \mathrm{~min}, 70 \% \mathrm{~B} ; 0.5-3.00 \mathrm{~min}, 70 \%-$ $100 \% \mathrm{~B} ; 3.00-11.00 \mathrm{~min}, 100 \% \mathrm{~B}$; the eluent was adjusted to its initial composition in 2 min. The column and autosampler were maintained at $25{ }^{\circ} \mathrm{C}$ and $4{ }^{\circ} \mathrm{C}$, respectively, and the column back pressure was 13,000 psi. Final ESI conditions were: source temperature $120{ }^{\circ} \mathrm{C}$, desolvation temperature $500{ }^{\circ} \mathrm{C}$, cone gas flow $50 \mathrm{~L} \cdot \mathrm{h}^{-1}$, desolvation gas flow $1000 \mathrm{~L} \cdot \mathrm{h}^{-1}$, capillary voltage $2.5 \mathrm{kV}$, sampling cone voltage $35 \mathrm{~V}$, and source offset $80 \mathrm{~V}$. The instrument was set to acquire over the $m / z$ range $50-1200$ with a scan time equal to $0.5 \mathrm{~s}$. Data were collected in the positive $\left(\mathrm{ESI}^{+}\right)$electrospray ionization modes using the $\mathrm{MS}^{\mathrm{E}}$ function in centroid mode, with a $6 \mathrm{~V}$ collision energy in function 1 (parent ions experiment) and a collision energy ramp of 20-40 V in function 2 (fragment ions experiment) (frequency of low to high collision switch $=30 \mathrm{~Hz})$. Leucine Enkephalin $(\mathrm{MW}=555.62 \mathrm{Da})\left(1 \mathrm{ng} \cdot \mu \mathrm{L}^{-1}\right)$ was used as the lock mass for mass shift correction. The mass spectrometer was calibrated before analyses using $0.5 \mathrm{mM}$ sodium formate solution. The mass error between experimental and theoretical parent and fragment ions was calculated as (|experimental $\mathrm{m} / \mathrm{z}$-theoretical $\mathrm{m} / \mathrm{z}$ | theoretical $\mathrm{m} / \mathrm{z}) \times 10^{6}(\mathrm{ppm})$.

\subsubsection{Software}

$M S^{\mathrm{E}}$ data were recorded in a centroid mode and analyzed using the MassLynx software. The MassFragment software was used to identify and propose a structure for each pigment ion fragment. The Metabolynx XS software was used to define if some ions could sign the 
presence of pigment metabolites according to the possible phase 1 (oxidation, reduction, hydrolysis), phase 2 (conjugation) or extraction (hydroxylation) biotransformations.

\subsection{Antiproliferative activity of $\mathrm{Ht}$ pigments in A2058 human melanoma cells}

The antiproliferative activity of $H t$ pigments ethanol extract or $H t$ purified pigments was studied in the A2058 (ATCC ${ }^{\circledR}$ CRL-11147'TM) cell line. A2058 are highly invasive human epithelial adherent melanoma cells, derived from lymph nodes metastatic cells obtained from a 43 years male patient [36]. They are tumorigenic at $100 \%$ frequency in nude mice, and considered as very resistant to anticancer drugs. All cell culture experiments were performed at $37^{\circ} \mathrm{C}$. Cells were grown to confluence in $75 \mathrm{~cm}^{2}$ flasks in DMEM supplemented with $10 \%$ fetal calf serum (FCS) and 1\% Penicillin-streptomycin (Dominique Dutscher, France), in a $5 \% \mathrm{CO}_{2}$ humidified atmosphere. The algal extracts and purified pigments were dried and solubilized in DMSO before being diluted in the cell culture medium to a final concentration

of $100 \mu \mathrm{g} \cdot \mathrm{mL}^{-1}$. The final DMSO concentration was lower than $1 \%$ and tested as a negative control. Cell viability at $72 \mathrm{~h}$ was studied using the MTT assay in 96-well microplates as previously described [20,37].

\subsection{Statistical analysis}

Data were expressed as percentage growth inhibition \pm SEM from 3 independent assays. The normal distribution of absorbance data in control and treated cells was demonstrated using the Hartley's Fmax test to confirm homogeneity of absorbances variances. The statistical significance of proliferation differences between control and treated cells was then investigated by an unpaired Student $t$ test, using a free online calculator developed by Institut 
Pierre Louis d'Epidémiologie et de Santé publique UMR S 1136 INSERM University Pierre et Marie Curie Paris (http://marne.u707.jussieu.fr/biostatgv/?module=tests).

\section{Results}

\subsection{Microwave-assisted extraction of $\mathrm{Ht}$ pigments}

Mixing freeze-dried $H t$ cells with ethanol only allowed an incomplete extraction of pigments (Figure 1A). This may be explained by a partial rupture

of $H t$ cell wall during the freeze-drying process. Soaking in ethanol at $50^{\circ} \mathrm{C}$ for $30 \mathrm{~min}$ or sonicating for $5 \mathrm{~min}$ at $50 \mathrm{~W}-30 \mathrm{KHz}$ increased the pigment extraction yield but did not allow a complete extraction according to the color of the cell pellet (Figure 1B and $1 \mathrm{C}$ respectively). MAE was the only process leading to a total extraction of pigments from $H t$ cells (Figure 1D). The possible loss of thecal plates during the centrifugation step used to collect $H t$ cells from the culture medium [38] was excluded, according to the SEM observations of $H t$ cells before pigment extraction (Figure 2A and 2B).

Figure 1. $H t$ ethanolic suspension before pigment extraction (A), after 30 min soaking at $50^{\circ} \mathrm{C}(\mathrm{B})$, after $5 \mathrm{~min}$ sonication (C) or after $5 \mathrm{~min}$ MAE at $50^{\circ} \mathrm{C}(\mathrm{D})$. MAE was the only process allowing the total extraction of $H t$ pigments, according to the color of $H t$ biomass. 


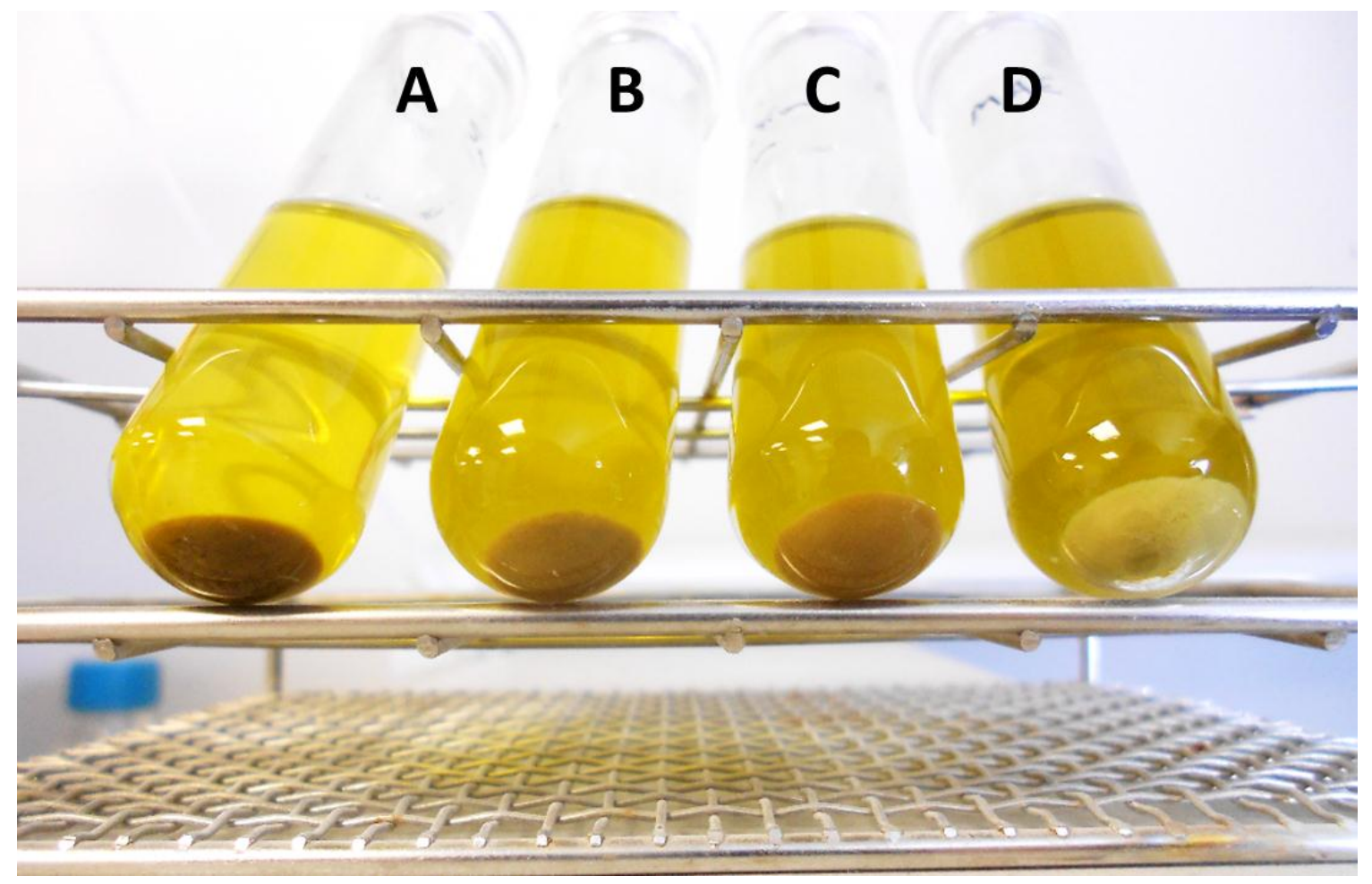

Figure. 2. Scanning electron microscopy observation of freeze-dried $H t$ cells before MAE extraction $(\mathrm{A}, \mathrm{B})$ and after $5 \mathrm{~min} \mathrm{MAE}$ at $50{ }^{\circ} \mathrm{C}(\mathrm{C}, \mathrm{D})$. Magnification $\times 3,000(\mathrm{~A}, \mathrm{C}) ; \times 6,000$ $(\mathrm{B}, \mathrm{D})$. 

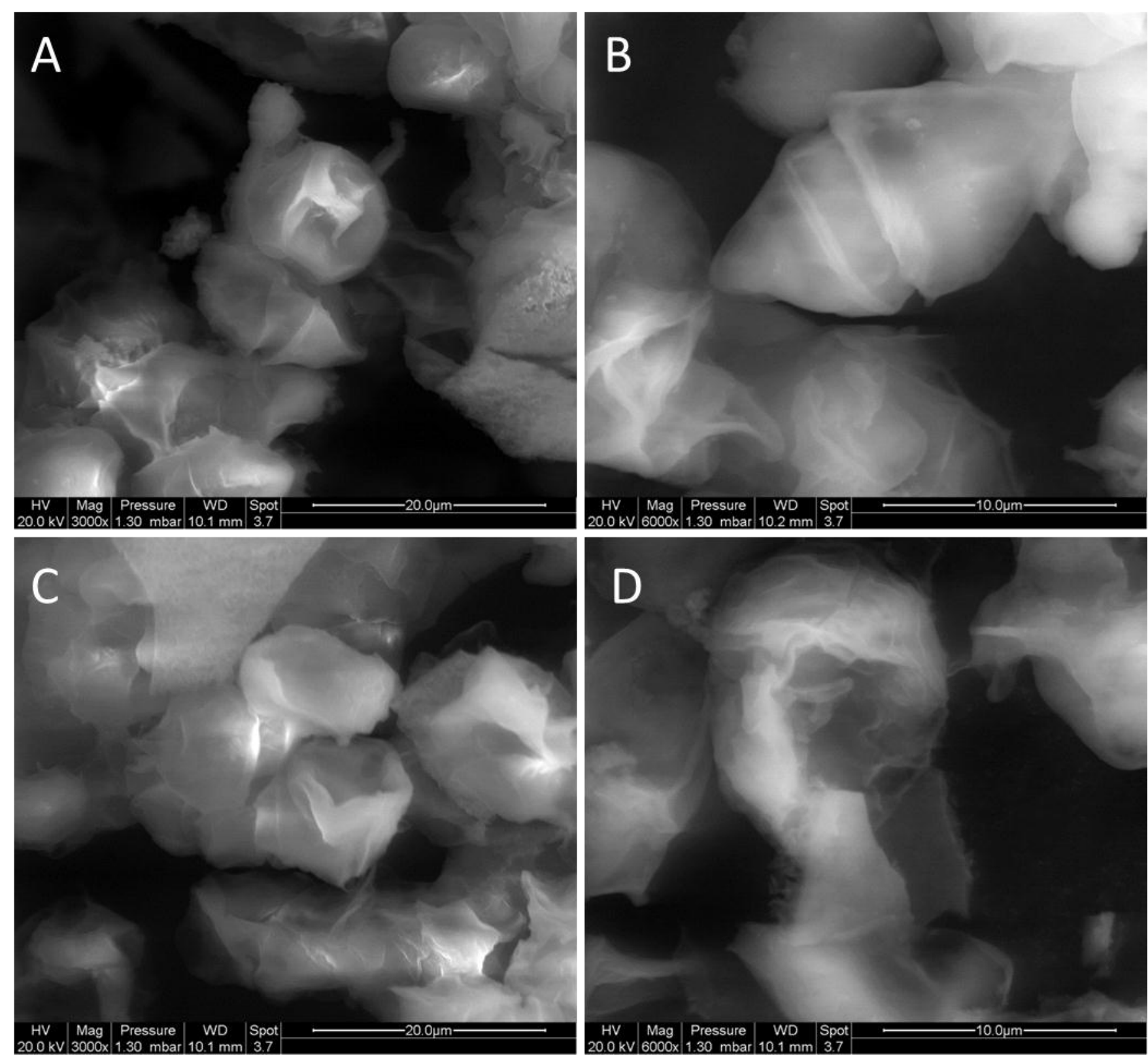

Scanning electron microscopy observation of freeze-dried $H t$ cells before MAE (Figure 2A and $2 \mathrm{~B}$ ) revealed the presence of clustered ovoid cells containing a biconic cell wall and a medium circular cingulum, coherent with the expected morphology of Ht cells [39]. Some cells showed signs of cell wall shrinkage that may be due to dehydration during the freeze-dry process but for most of them, no cell wall disruption or loss of cellulosic plates could be observed before MAE. In contrast, observation of $H t$ cells after MAE of pigments (Figure $2 \mathrm{C}$ and 2D) evidenced cell wall tearing allowing the direct contact of ethanol with the intracellular content. 


\subsection{RP-HPLC fractionation, collection and identification of $\mathrm{Ht}$ pigments}

Eleven major colored peaks or fractions were distinguished and collected for molecular characterization and antiproliferative assay in melanoma cells (Figure 3. and 4.). According to their colors and absorption spectra, the collected fractions were classified as containing chlorophyll or derivatives (fractions 2, 8, 9 and 10) or carotenoids (fractions 1, 3, 4, 5, 6, 7 and 11). A colorless fraction (fraction 0, Rt: $7.00 \mathrm{~min}$ ) that was only present in two of the three extracts was collected together with fractions 1-11 when detected. Identification of all pigments and derivatives was performed by cross-check analysis of polarity, pigmentation, absorption spectra, maximal absorption wavelengths in HPLC eluents, band III/II ratios and taxonomic coherence of the presence of the pigment in Ht (Table 1.). This preliminary identification was confirmed by the $\mathrm{m} / \mathrm{z}$ of parent and fragments ions detected after injection of RP-HPLC peaks or fractions in UPLC-MS ${ }^{\mathrm{E}}$ (Table. 2.).

Figure 3. RP-HPLC chromatogram at $435 \mathrm{~nm}$ of $\mathrm{Ht}$ ethanol extract and definition of the eleven peaks/fractions collected for molecular characterization and antiproliferative assay. Fraction 0, corresponding to the peak eluting at 7.00 min was present in two of the three extracts and collected for tentative identification. 


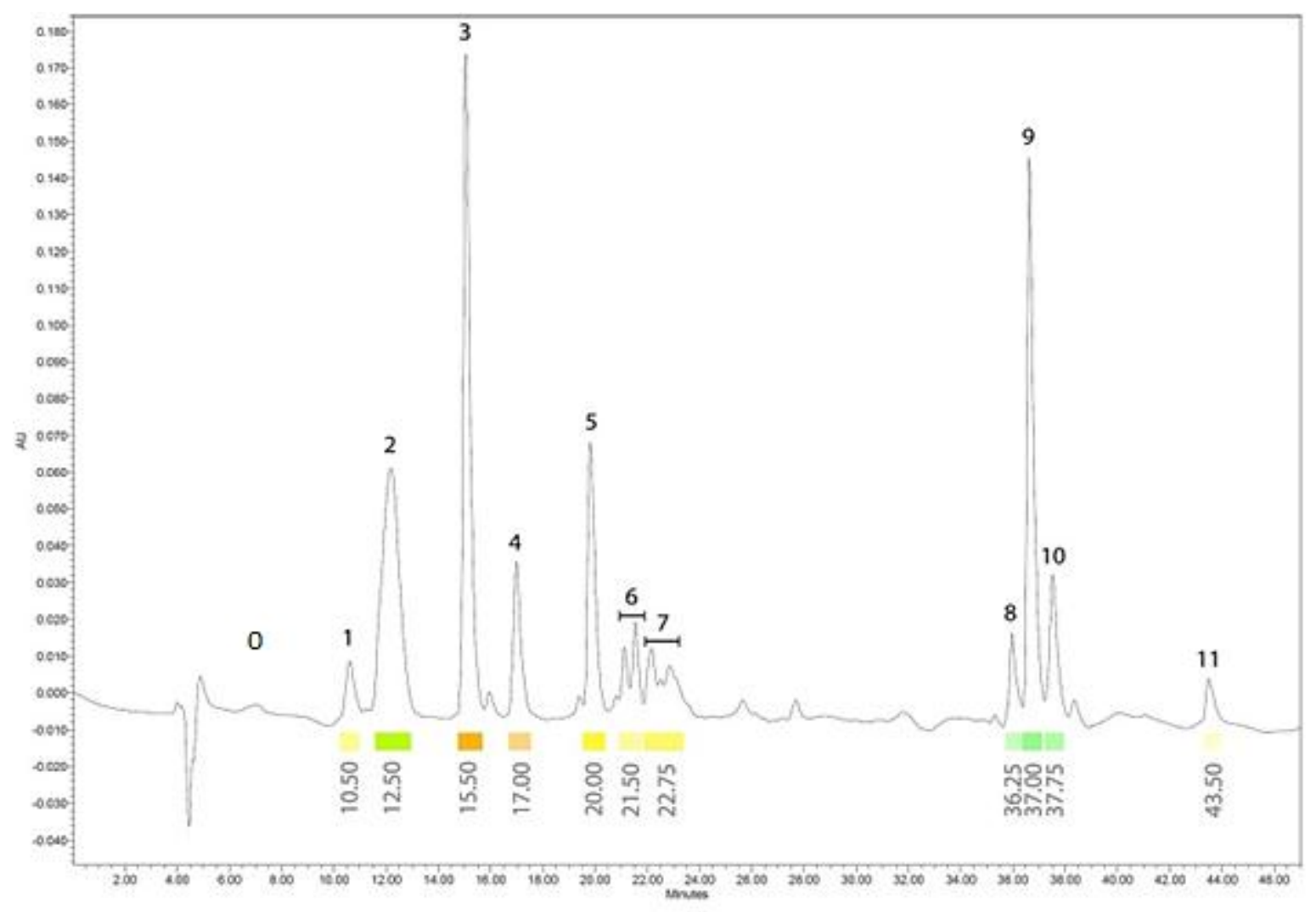

Figure 4. Fractions collected by preparative RP-HPLC from Ht ethanol extract.

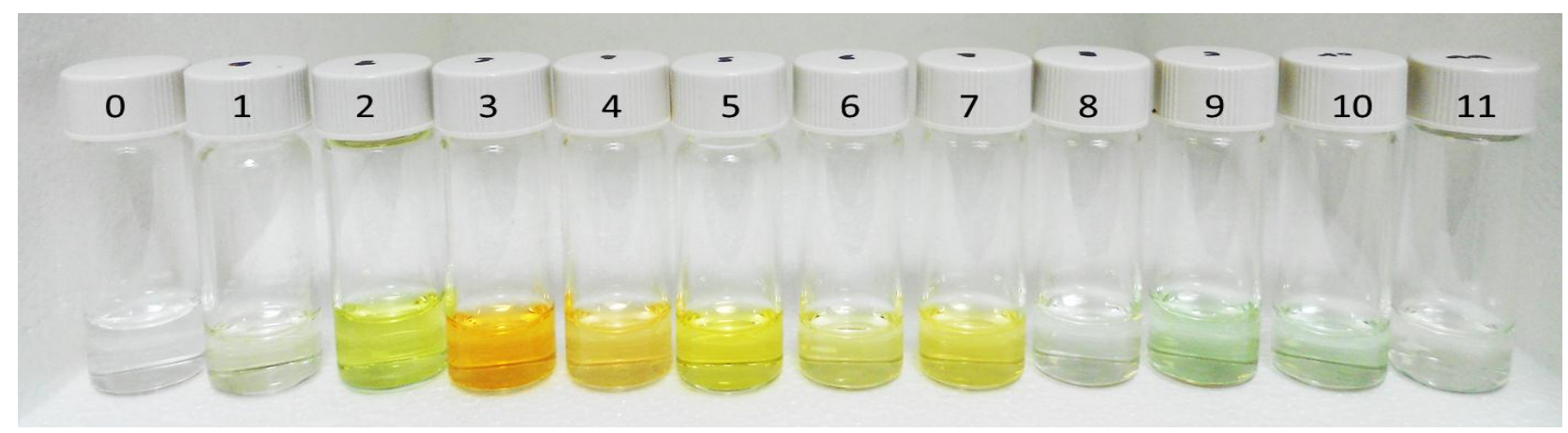


Table 1. Identification of $H t$ pigments based on chromatographic characteristics of RP-

HPLC fractions and taxonomic coherence. ND : non determinable.

\begin{tabular}{|c|c|c|c|c|c|}
\hline Peak/fraction & $\begin{array}{l}\text { RP-HPLC Rt } \\
(\text { min) }\end{array}$ & Color & $\lambda_{\text {max }}(\mathbf{n m})$ & Identification & $\begin{array}{l}\text { Taxonomic coherence } \\
\text { according to [39] } \\
\text { (page 37) }\end{array}$ \\
\hline $\begin{array}{l}0 \\
\text { Intermittent } \\
\text { peak }\end{array}$ & 7.00 & Colorless & ND & Mg DVP & $\begin{array}{l}\text { Reported in DINO-1 } \\
\text { chlorophylls precursor }\end{array}$ \\
\hline 1 & 10.50 & Yellow & 446.3 & P457 & $\begin{array}{l}\text { Carotenoid lactoside } \\
\text { present in DINO-1 }\end{array}$ \\
\hline \multirow[t]{2}{*}{2} & \multirow[t]{2}{*}{12.50} & \multirow[t]{2}{*}{ Green } & $\begin{array}{l}453.3 \\
589.3 \\
638.3\end{array}$ & Chlorophyll $c 2$ & Present in DINO-1 \\
\hline & & & ND & $\begin{array}{l}\text { Peridininol } \\
\left(\mathrm{MS}^{\mathrm{E}} \text { analysis) }\right.\end{array}$ & Present in DINO-1 \\
\hline 3 & 15.50 & Orange & 474.3 & Peridinin & \multirow{2}{*}{$\begin{array}{l}\text { Lactone-ring containing } \\
\text { carotenoid characterizing } \\
\text { DINO-1 (peridinin- } \\
\text { containing dinoflagellates) }\end{array}$} \\
\hline 4 & 17.00 & Orange & 462.1 & $\begin{array}{l}\text { Peridinin } \\
\text { isomer [40] }\end{array}$ & \\
\hline \multirow[t]{3}{*}{5} & \multirow[t]{3}{*}{20.00} & \multirow[t]{3}{*}{ Yellow } & 459.7 & $\begin{array}{l}\text { Pyrrhoxanthin } \\
\text { [41] }\end{array}$ & $\begin{array}{l}\text { Lactone-ring containing } \\
\text { carotenoid present in } \\
\text { DINO-1 }\end{array}$ \\
\hline & & & $\begin{array}{l}407.3 \\
429.3 \\
457.3 \\
\text { band III/II ratio } \\
=58 \%\end{array}$ & Diadinochrome & $\begin{array}{l}\text { Produced by } \\
\text { diadinoxanthin } \\
\text { rearrangement in weakly } \\
\text { acidic solutions }\end{array}$ \\
\hline & & & $\begin{array}{l}420.3 \\
447.5 \\
478.0 \\
\text { band III/II ratio } \\
=68 \%\end{array}$ & Diadinoxanthin & Present in DINO-1 \\
\hline 6 & 21.50 & Yellow & $\begin{array}{l}446.3 \\
470.6 \\
\text { band III/II ratio } \\
=85 \%\end{array}$ & Dinoxanthin & $\begin{array}{l}\text { Minor carotenoid in DINO- } \\
1\end{array}$ \\
\hline 7 & 22.75 & Yellow & 446.3 & Diatoxanthin & Present in DINO-1 \\
\hline
\end{tabular}




\begin{tabular}{|c|c|c|c|c|c|}
\hline & & & $\begin{array}{l}471.9 \\
\text { band III/II ratio } \\
=33 \%\end{array}$ & & \\
\hline 8 & 36.25 & Gray & $\begin{array}{l}422.0 \\
661.0\end{array}$ & $\begin{array}{l}\text { Hydroxy- } \\
\text { chlorophyll } a\end{array}$ & $\begin{array}{l}\text { Hydroxylation of } \\
\text { chlorophyll } a \text { during } \\
\text { ethanolic extraction [30] }\end{array}$ \\
\hline 9 & 37.00 & Green & $\begin{array}{l}429.3 \\
660.5\end{array}$ & Chlorophyll $a$ & $\begin{array}{l}\text { Ubiquitary in } \\
\text { phytoplankton }\end{array}$ \\
\hline \multirow[t]{2}{*}{10} & 37.75 & Green & $\begin{array}{l}430.6 \\
663.0\end{array}$ & $\begin{array}{l}\text { Chlorophyll } a \\
\text { epimer }\end{array}$ & $\begin{array}{l}\text { Epimerization of } \\
\text { chlorophyll } a[20]\end{array}$ \\
\hline & & & $\begin{array}{l}410.0 \\
666.7\end{array}$ & Pheophytin $a$ & $\begin{array}{l}\text { Pheophytination of } \\
\text { chlorophyll } a \text { during } \\
\text { extraction [20] }\end{array}$ \\
\hline 11 & 43.50 & Orange & $\begin{array}{l}453.6 \\
479.4 \\
\text { band III/II ratio } \\
=27 \%\end{array}$ & $\beta, \beta$-carotene & $\begin{array}{l}\text { Present in most } \\
\text { phytoplankton species } \\
\text { including DINO-1 }\end{array}$ \\
\hline
\end{tabular}

Diadinochrome (fraction 5) [25], hydroxy-chlorophyll $a$ (peak 8) [30] and pheophytin $a$ (fraction 10) were identified as pigment derivatives produced during $H t$ ethanolic extraction. The retention time of hydroxy-chlorophyll $a$ was slightly lower than that of chlorophyll $a$ (peak 9) in accordance with a gain of polarity due to hydroxylation. Pheophytination of chlorophyll $a$ in the $H t$ pigment ethanol extract may be due the heat increase during MAE, as this chlorophyll $a$ derivative is absent or minority in phytoplankton living cells [20]. Ubiquitous phytoplankton pigments or precursors were identified in peak 0 (magnesium 2,4divinylpheoporphyrin $a_{5}$ monomethyl ester; Mg-DVP [25]), peak 9 (chlorophyll $a$ ), fraction 10 (chlorophyll a epimer) [20] and peak 11 ( $\beta, \beta$-carotene). Pigments and derivatives previously reported in the DINO-1 peridiniales order and present in $H t$ living cells were also unequivocally identified: P457 (peak 1) [42,43], chlorophyll c2 (fraction 2) [25,44], peridininol (fraction 2), peridinin (peak 3) [25,45], peridinin isomer (peak 4) [40], 
pyrrhoxanthin (fraction 5) [25,41,45], diadinoxanthin (fraction 5), dinoxanthin (peak 6), diatoxanthin and 9-cis diatoxanthin isomer (peak 7) [46].

Table 2. UPLC-MS ${ }^{\mathrm{E}}$ confirmation of $H t$ pigment composition. 


\begin{tabular}{|c|c|c|c|c|c|c|c|c|c|c|c|c|}
\hline \multirow[b]{3}{*}{ Pigment identification } & \multirow[b]{3}{*}{ Formula } & \multirow[b]{3}{*}{$\operatorname{Rt}(\min )$} & \multicolumn{6}{|c|}{ Function 1 (Low collision energy) } & \multicolumn{4}{|c|}{ Function 2 (High collision energy) } \\
\hline & & & \multicolumn{3}{|c|}{ Theorical $\mathrm{m} / \mathrm{z}$} & \multicolumn{3}{|c|}{ Experimental $\mathrm{m} / \mathrm{z}$} & \multicolumn{2}{|c|}{ Theorical m/z } & \multicolumn{2}{|c|}{ Experimental $\mathrm{m} / \mathrm{z}$} \\
\hline & & & $\mathrm{M}^{\bullet+}$ & {$[\mathrm{M}+\mathrm{H}]^{+}$} & {$[\mathrm{M}+\mathrm{Na}]^{+}$} & $\mathrm{M}^{\bullet+}$ & {$[\mathrm{M}+\mathrm{H}]^{+}$} & {$[\mathrm{M}+\mathrm{Na}]^{+}$} & Fragments & Fragments & Fragments & Fragments \\
\hline P457 & $\mathrm{C}_{52} \mathrm{H}_{76} \mathrm{O}_{15}$ & $2.45-2.84$ & 940.5184 & - & 963.5082 & $\begin{array}{l}940.5188 \\
(0.4 \mathrm{ppm})\end{array}$ & - & $\begin{array}{l}963.5082 \\
(0.0 \mathrm{ppm})\end{array}$ & 563.3889 & - & $\begin{array}{l}563.3897 \\
(1.4 \mathrm{ppm})\end{array}$ & - \\
\hline Chlorophyll $c 2$ & $\mathrm{C}_{35} \mathrm{H}_{28} \mathrm{~N}_{4} \mathrm{O}_{5} \mathrm{Mg}$ & 3.84 & - & 609.1988 & 631.1808 & - & $\begin{array}{c}609.1988 \\
(\mathbf{0 . 0} \mathbf{~ p p m}) \\
\end{array}$ & $\begin{array}{l}631.1818 \\
(1.6 \mathrm{ppm})\end{array}$ & 549.1777 & - & $\begin{array}{l}549.1774 \\
(0.5 \mathrm{ppm})\end{array}$ & - \\
\hline Peridininol & $\mathrm{C}_{37} \mathrm{H}_{48} \mathrm{O}_{6}$ & 2,62 & 588.3451 & - & 611.3349 & $\begin{array}{c}588.3451(4.8 \\
\text { ppm) }\end{array}$ & - & $\begin{array}{l}611.3369 \\
\text { (3.3 ppm) }\end{array}$ & - & - & - & - \\
\hline Peridin & $\mathrm{C}_{39} \mathrm{H}_{50} \mathrm{O}_{7}$ & $3.22-3.68$ & - & - & 653.3454 & - & $\begin{array}{l}653.3456 \\
(0.3 \mathrm{ppm})\end{array}$ & - & 575.3137 & - & $\begin{array}{l}575.3128 \\
(1.6 \mathrm{ppm})\end{array}$ & - \\
\hline Peridin isomer & $\mathrm{C}_{39} \mathrm{H}_{50} \mathrm{O}_{7}$ & $3.21-3.66$ & - & - & 653.3454 & - & $\begin{array}{l}653.3458 \\
(0.6 \mathrm{ppm}) \\
\end{array}$ & - & 575.3137 & - & $\begin{array}{l}575.3148 \\
(1.8 \mathrm{ppm}) \\
\end{array}$ & - \\
\hline Pyrrhoxanthin & $\mathrm{C}_{39} \mathrm{H}_{48} \mathrm{O}_{6}$ & 3.85 & 612.3451 & 613.3529 & 635.3349 & $\begin{array}{l}612.3445 \\
(1.0 \mathrm{ppm})\end{array}$ & $\begin{array}{c}613.3507 \\
(3.6 \mathrm{ppm})\end{array}$ & $\begin{array}{l}635.3350 \\
(0.2 \mathrm{ppm})\end{array}$ & 575.3137 & 557.3032 & $\begin{array}{l}575.3135 \\
(1.2 \mathrm{ppm})\end{array}$ & - \\
\hline $\begin{array}{l}\text { Diadinoxanthin } \\
\text { Diadinochrome }\end{array}$ & $\mathrm{C}_{40} \mathrm{H}_{54} \mathrm{O}_{3}$ & 4.02 & 582.4073 & 583.4151 & 605.3971 & $\begin{array}{l}582.4074 \\
(0.2 \mathrm{ppm})\end{array}$ & $\begin{array}{c}583.4143 \\
(1.4 \mathrm{ppm})\end{array}$ & $\begin{array}{l}605.3976 \\
(0.8 \mathrm{ppm})\end{array}$ & 565.4046 & 587.3865 & $\begin{array}{l}565.4045 \\
(0.2 \mathrm{ppm})\end{array}$ & $\begin{array}{l}587.3864 \\
(0.2 \mathrm{ppm})\end{array}$ \\
\hline Dinoxanthin & $\mathrm{C}_{42} \mathrm{H}_{58} \mathrm{O}_{5}$ & 4.04 & 642.4284 & - & 665.4182 & $\begin{array}{l}642.4273 \\
(1.7 \mathrm{ppm})\end{array}$ & - & $\begin{array}{l}665.4180 \\
(0.3 \mathrm{ppm})\end{array}$ & 565.4035 & - & $\begin{array}{l}565.4025 \\
(1.8 \mathrm{ppm})\end{array}$ & - \\
\hline Diatoxanthin & $\mathrm{C}_{40} \mathrm{H}_{54} \mathrm{O}_{2}$ & 4.21 & 566.4124 & - & - & $\begin{array}{l}566.4111 \\
(2.3 \mathrm{ppm})\end{array}$ & - & - & - & - & - & - \\
\hline Hydroxy-chlorophyll $a$ & $\mathrm{C}_{55} \mathrm{H}_{72} \mathrm{O}_{6} \mathrm{~N}_{4} \mathrm{Mg}$ & 5.43 & 908.5302 & - & 931.52 & $\begin{array}{l}908.5286 \\
(1.8 \mathrm{ppm})\end{array}$ & - & $\begin{array}{l}931.5201 \\
(0.1 \mathrm{ppm})\end{array}$ & 630.2329 & - & $\begin{array}{l}630.2314 \\
(2.4 \mathrm{ppm})\end{array}$ & - \\
\hline Chlorophyll $a$ & $\mathrm{C}_{55} \mathrm{H}_{72} \mathrm{O}_{5} \mathrm{~N}_{4} \mathrm{Mg}$ & 5.74 & 892.5353 & 893.5431 & 915.5251 & $\begin{array}{l}892.5348 \\
(0.6 \mathrm{ppm}) \\
\end{array}$ & $\begin{array}{c}893.5402 \\
\text { (3.6 ppm) } \\
\end{array}$ & $\begin{array}{l}915.5241 \\
(1.1 \mathrm{ppm})\end{array}$ & 614.238 & 481.1879 & $\begin{array}{l}614.2382 \\
(0.3 \mathrm{ppm}) \\
\end{array}$ & $\begin{array}{l}481.1873 \\
(1.2 \mathrm{ppm}) \\
\end{array}$ \\
\hline Pheophytin $a$ & $\mathrm{C}_{55} \mathrm{H}_{74} \mathrm{O}_{5} \mathrm{~N}_{4}$ & $8.99-9.31$ & - & 871.5737 & 893.5557 & - & $\begin{array}{c}871.5736 \\
(0.1 \mathrm{ppm})\end{array}$ & $\begin{array}{l}893.5560 \\
\text { (0.3 ppm) }\end{array}$ & 593.2764 & 533.2553 & $\begin{array}{l}593.2780 \\
(2.7 \mathrm{ppm})\end{array}$ & - \\
\hline$\beta, \beta$-Carotene & $\mathrm{C}_{40} \mathrm{H}_{56}$ & 8.1 & 536.4382 & - & - & $\begin{array}{l}536.4380 \\
(0.4 \mathrm{ppm})\end{array}$ & - & - & 444.3756 & - & $\begin{array}{l}444.3752 \\
(0.9 \mathrm{ppm})\end{array}$ & - \\
\hline
\end{tabular}


The chemical structures of pigments contained in the $H t$ cells and recovered in the ethanol extract are presented in Figure 5.

Figure 5. Chemical structures of pigments and derivatives identified in the $H t$ ethanol extract.

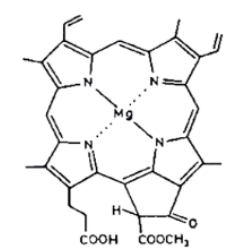

Mg DVP
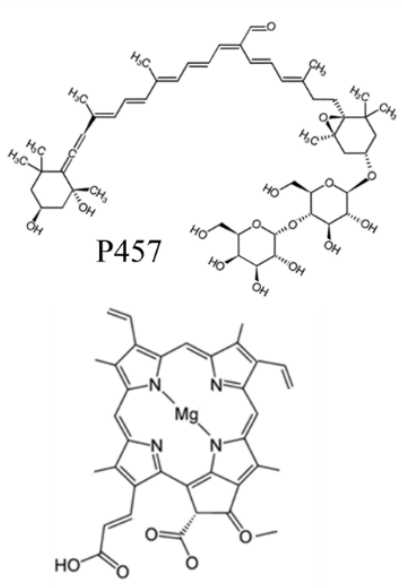

Chlorophyll $c 2$
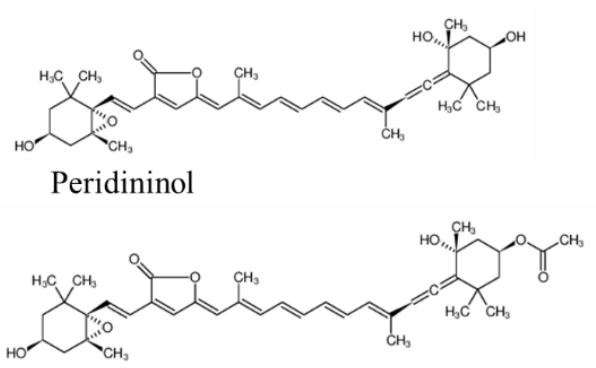

Peridinin
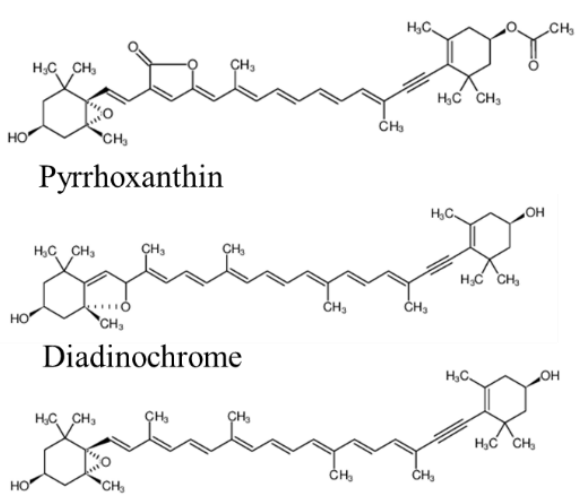

Diadinoxanthin
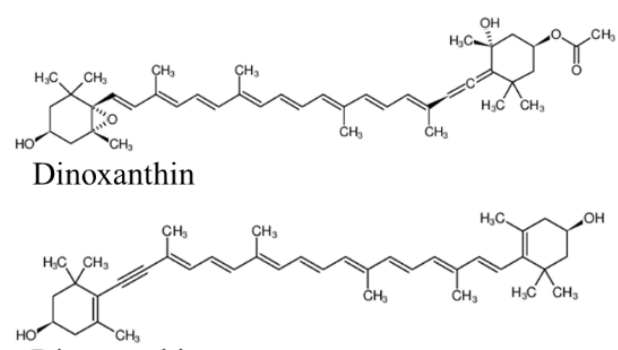

Diatoxanthin
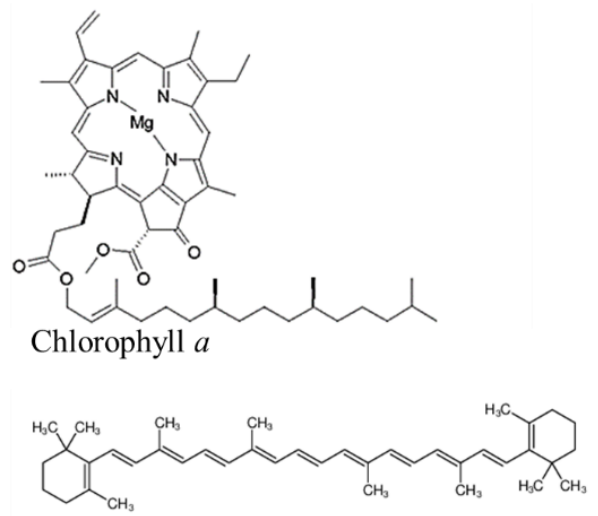

$\beta, \beta$-carotene

\subsection{Antiproliferative activity of $\mathrm{Ht}$ pigments in A2058 melanoma cells}

$H t$ ethanol extract induced $18.5 \pm 8.1 \%$ growth inhibition, that was not significant according to the $t$ test $(\mathrm{n}=3)$ (Table 3.). Four pigments, chlorophyll $c 2$, peridinin, dinoxanthin and diatoxanthin could be purified in sufficient amounts to prepare $100 \mu \mathrm{g} \cdot \mathrm{mL}^{-1}$ solutions in the melanoma cell culture medium. These four pigments all induced a highly significant growth inhibition ( $\mathrm{p}<0.01, t$ test, $\mathrm{n}=3$ ), ranging from $25.6 \pm 4.0$ to $47.2 \pm 8.7 \%$ (Table. 3 .). 
Table 3. A2058 growth inhibition (\%) after a $72 \mathrm{~h}$ treatment with $100 \mu \mathrm{g} \cdot \mathrm{mL}^{-1} \mathrm{Ht}$ ethanol extract and purified pigments obtained from RP-HPLC fractionation. $(n=3)$. $t$ test (treated vs control) : $* \mathrm{p}<0.05, * * \mathrm{p}<0.01 . \mathrm{NS}:$ Non significative.

\begin{tabular}{|c|c|}
\hline Extract or molecule & \% growth inhibition \pm SEM \\
\hline$H t$ ethanol extract & $18.5 \pm 8.1(\mathrm{NS})$ \\
\hline Chlorophyll $c 2$ & $47.2 \pm 8.7 * *$ \\
\hline Peridinin & $25.6 \pm 4.0^{* *}$ \\
\hline Dinoxanthin & $34.4 \pm 5.2 * *$ \\
\hline Diatoxanthin & $34.5 \pm 5.8^{* *}$ \\
\hline
\end{tabular}

Chlorophyll $c 2$ was identified as the most active pigment in $H t$ extract, inhibiting almost half of A2058 growth. Microscopic observation of A2058 melanoma cells confirmed that the $\mathrm{Ht}$ ethanol extract, chlorophyll $c 2$, peridinin, dinoxanthin and diatoxanthin lowered the cell density as compared to untreated cells (Figure 6.). No sign of morphological changes such as cell shrinkage or blebbing were observed, suggesting that the pigments antiproliferative activity may not be related to a high cytotoxicity or pro-apoptotic activity, as previously reported for some carotenoids and chlorophyll derivatives [12,20,47]. The molecular mechanisms involved in this antiproliferative activity remain to be established in future studies.

Figure 6. Microphotographs of A2058 melanoma cells after a $72 \mathrm{~h}$ exposition to a control cell culture medium (A) or to a medium containing $100 \mu \mathrm{g} \cdot \mathrm{mL}^{-1}$ of $H t$ ethanol extract (B), chlorophyll $c 2(\mathrm{C})$, peridinin $(\mathrm{D})$, dinoxanthin $(\mathrm{E})$ or diatoxanthin $(\mathrm{F})$. The antiproliferative activity of $H t$ ethanol extract and purified pigments was confirmed by observation of a decrease in the cell density as compared to untreated cells. No cell condensation or fragmentation into apoptotic bodies could be observed, suggesting that the antiproliferative activity may not be related to a pro-apoptotic effect. 

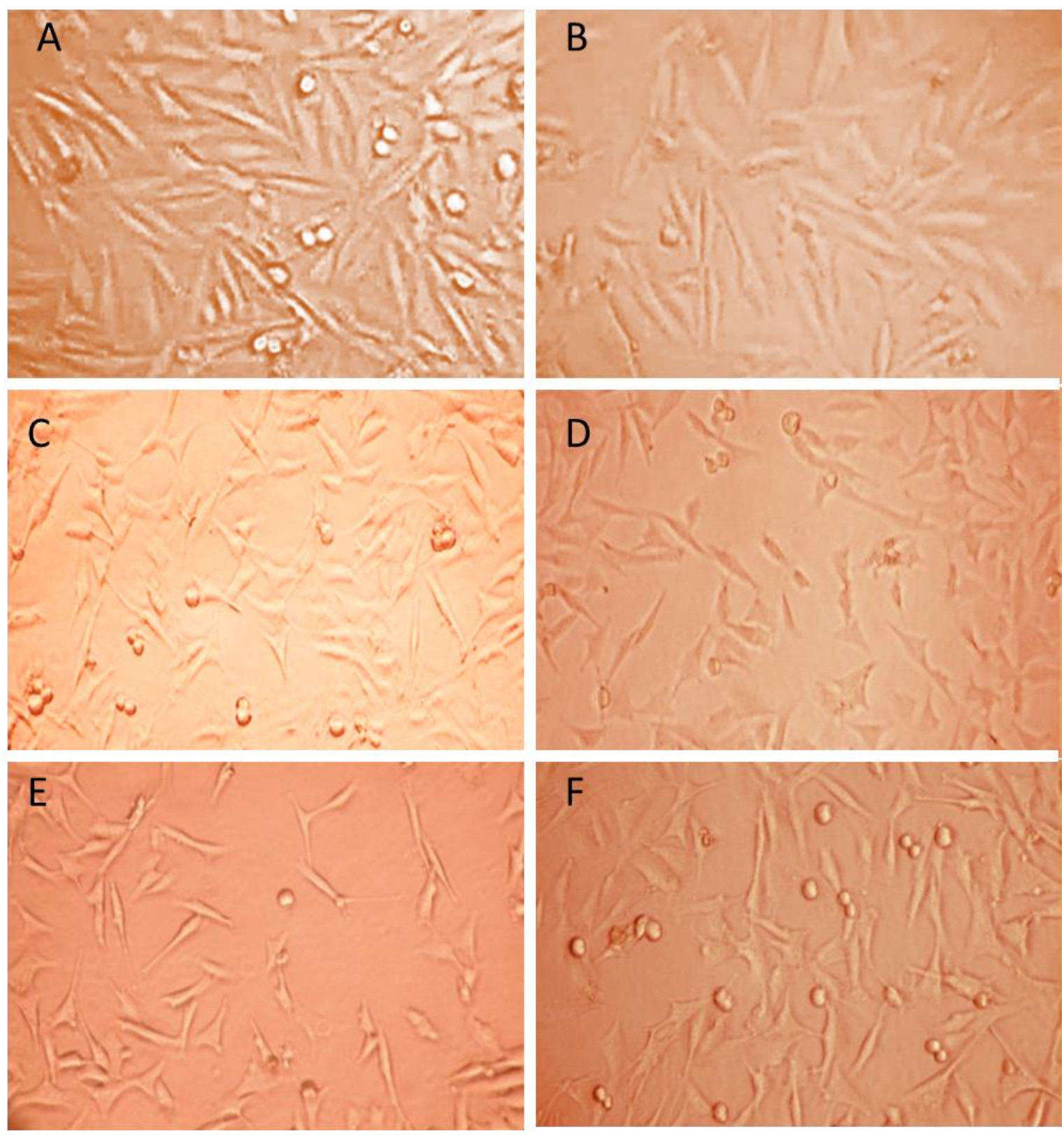

\section{Discussion}

In this study, we investigated the pigment composition of $H t$, a non-toxic dinophyte and evaluated their antiproliferative activity in human metastatic melanoma cells in vitro. To extract pigments, we performed the first microwave-assisted extraction (MAE) of chlorophylls and carotenoids from a dinophyte species. Ht pigments composition was unequivocally determined using an innovative UPLC-MS ${ }^{\mathrm{E}}$ analysis. MAE allowed the 
fracturing of $H t$ cellulosic armour, as demonstrated by scanning electron microscopy observations and combined the qualities of a powerful pigment extraction process compared with soaking or sonication : rapidity, easiness, low cost, eco-efficiency, reproducibility, high extraction yields, and controlled conditions limiting the thermal damage of chlorophylls and carotenoids. The $H t$ ethanol extract contained pigment derivatives produced during the ethanolic extraction, ubiquitous phytoplankton pigments and specific DINO-1 pigments. Particularly, $H t$ was confirmed as an interesting source to purify original pigments such as the carotenoid lactoside P457, epoxycarotenoids (pyrrhoxanthin, diadinochrome, peridinin and peridininol) and dinoxanthin (only present in dinophytes). Purification of $H t$ pigments and evaluation of their biological activity in human melanoma cells evidenced a moderate to high antiproliferative activity of chlorophyll $c 2$, diatoxanthin and dinoxanthin. This antiproliferative activity was associated to a low cytotoxic activity, according to the morphological observations of melanoma cells treated with a cell culture medium containing $100 \mu \mathrm{g} \cdot \mathrm{mL}^{-1}$ of these pigments. These observations suggest a cytostatic activity at this concentration, rather than a pro-apoptotic effect, and the molecular mechanisms involved in this antiproliferative activity remain to be established. We also demonstrated the moderate antiproliferative activity of peridinin in melanoma cells, and this observation was coherent with previous data obtained on HeLa, Caco-2, DLD-1 and K562 cells [12]. This study highlights the biological activity of minor phytoplankton pigments that had never been studied before because of their low abundance. These data, combined to previous results obtained with major carotenoids such as fucoxanthin and zeaxanthin, reinforce the hypothesis that phytoplankton pigments may have a great potential to limit melanoma growth in vivo. According to their ability to cross the intestinal barrier and reach tumor cells from the bloodstream, the cytostatic activity of phytoplankton pigments may be of high interest to limit apoptosis resistance and acquisition of a multi-drug resistant phenotype. 


\section{References}

[1] F. Grange, [Epidemiology of cutaneous melanoma: descriptive data in France and Europe]., Ann. Dermatol. Venereol. 132 (2005) 975-82. http://www.ncbi.nlm.nih.gov/pubmed/16446640 (accessed March 27, 2014).

[2] R.M. MacKie, A. Hauschild, A.M.M. Eggermont, Epidemiology of invasive cutaneous melanoma., Ann. Oncol. 20 Suppl 6 (2009) vi1-7. doi:10.1093/annonc/mdp252.

[3] C. Locatelli, F.B. Filippin-Monteiro, T.B. Creczynski-Pasa, Recent Advances in the Biology, Therapy and Management of Melanoma, InTech, 2013. doi:10.5772/46052.

[4] K. Dutton-Regester, D. Irwin, P. Hunt, L.G. Aoude, V. Tembe, G.M. Pupo, C. Lanagan, C.D. Carter, L. O’Connor, M. O’Rourke, R.A. Scolyer, G.J. Mann, C.W. Schmidt, A. Herington, N.K. Hayward, A high-throughput panel for identifying clinically relevant mutation profiles in melanoma., Mol. Cancer Ther. 11 (2012) 88897. doi:10.1158/1535-7163.MCT-11-0676.

[5] S. Jang, M.B. Atkins, Treatment of BRAF-mutant melanoma: the role of vemurafenib and other therapies., Clin. Pharmacol. Ther. 95 (2014) 24-31. doi:10.1038/clpt.2013.197.

[6] G. Van Goietsenoven, J. Hutton, J.-P. Becker, B. Lallemand, F. Robert, F. Lefranc, C. Pirker, G. Vandenbussche, P. Van Antwerpen, A. Evidente, W. Berger, M. Prévost, J. Pelletier, R. Kiss, T.G. Kinzy, A. Kornienko, V. Mathieu, Targeting of eEF1A with Amaryllidaceae isocarbostyrils as a strategy to combat melanomas., FASEB J. 24 (2010) 4575-84. doi:10.1096/fj.10-162263. 
[7] K. Bonjean, M.C. De Pauw-Gillet, M.P. Defresne, P. Colson, C. Houssier, L. Dassonneville, C. Bailly, R. Greimers, C. Wright, J. Quetin-Leclercq, M. Tits, L. Angenot, The DNA intercalating alkaloid cryptolepine interferes with topoisomerase II and inhibits primarily DNA synthesis in B16 melanoma cells., Biochemistry. 37 (1998) 5136-46. doi:10.1021/bi972927q.

[8] A. Alqathama, J.M. Prieto, Natural products with therapeutic potential in melanoma metastasis, 32 (2015) 1170-1182. doi:10.1039/c4np00130c.

[9] T.N. Chinembiri, L.H. Du Plessis, M. Gerber, J.H. Hamman, J. Du Plessis, Review of natural compounds for potential skin cancer treatment, 19 (2014) 11679-11721. doi:10.3390/molecules190811679.

[10] J. Okuzumi, T. Takahashi, T. Yamane, Y. Kitao, M. Inagake, K. Ohya, H. Nishino, Y. Tanaka, Inhibitory effects of fucoxanthin, a natural carotenoid, on N-ethyl-N'-nitro-nnitrosoguanidine-induced mouse duodenal carcinogenesis., Cancer Lett. 68 (1993) $159-168$.

[11] H. Nishino, Cancer prevention by carotenoids., Mutat. Res. 402 (1998) 159-163.

[12] A.-L. Gagez, V. Thiery, V. Pasquet, J.-P. Cadoret, L. Picot, Epoxycarotenoids and Cancer. Review, Curr. Bioact. Compd. 8 (2012) 109-141. doi:10.2174/157340712801784787.

[13] V. Mimouni, L. Ulmann, V. Pasquet, M. Mathieu, L. Picot, G. Bougaran, J.-P. Cadoret, A. Morant-Manceau, B. Schoefs, The potential of microalgae for the production of bioactive molecules of pharmaceutical interest., Curr. Pharm. Biotechnol. 13 (2012) 2733-50. http://www.ncbi.nlm.nih.gov/pubmed/23072388 (accessed May 5, 2014).

[14] P. Gupta, D. Sinha, R. Bandopadhyay, Isolation and screening of marine microalgae 
Chlorella sp._PR1 for anticancer activity, Int. J. Pharm. Pharm. Sci. 6 (2014) 517-519. http://innovareacademics.in/journals/index.php/ijpps/article/view/2980 (accessed March 9, 2017).

[15] N. Gyémánt, M. Tanaka, P. Molnár, J. Deli, L. Mándoky, J. Molnár, Reversal of multidrug resistance of cancer cells in vitro: modification of drug resistance by selected carotenoids., Anticancer Res. 26 (2006) 367-374.

[16] J. Molnár, N. Gyémánt, I. Mucsi, A. Molnár, M. Szabó, T. Körtvélyesi, A. Varga, P. Molnár, G. Tóth, Modulation of multidrug resistance and apoptosis of cancer cells by selected carotenoids., In Vivo (Brooklyn). 18 (2004) 237-244.

[17] K.-N. Kim, G. Ahn, S.-J. Heo, S.-M. Kang, M.-C. Kang, H.-M. Yang, D. Kim, S.W. Roh, S.-K. Kim, B.-T. Jeon, P.-J. Park, W.-K. Jung, Y.-J. Jeon, Inhibition of tumor growth in vitro and in vivo by fucoxanthin against melanoma B16F10 cells., Environ. Toxicol. Pharmacol. 35 (2013) 39-46. doi:10.1016/j.etap.2012.10.002.

[18] T.-W. Chung, H.-J. Choi, J.-Y. Lee, H.-S. Jeong, C.-H. Kim, M. Joo, J.-Y. Choi, C.-W. Han, S.-Y. Kim, J.-S. Choi, K.-T. Ha, Marine algal fucoxanthin inhibits the metastatic potential of cancer cells., Biochem. Biophys. Res. Commun. 439 (2013) 580-5. doi:10.1016/j.bbrc.2013.09.019.

[19] M.-C. Bi, R. Rosen, R.-Y. Zha, S.A. McCormick, E. Song, D.-N. Hu, Zeaxanthin Induces Apoptosis in Human Uveal Melanoma Cells through Bcl-2 Family Proteins and Intrinsic Apoptosis Pathway., Evid. Based. Complement. Alternat. Med. 2013 (2013) 205082. doi:10.1155/2013/205082.

[20] P.-H. Baudelet, A.-L. Gagez, J.-B. Bérard, C. Juin, N. Bridiau, R. Kaas, V. Thiéry, J.-P. Cadoret, L. Picot, Antiproliferative activity of Cyanophora paradoxa pigments in 
melanoma, breast and lung cancer cells., Mar. Drugs. 11 (2013) 4390-406. doi:10.3390/md11114390.

[21] X.L. Xu, D.-N. Hu, C. Iacob, A. Jordan, S. Gandhi, D.L. Gierhart, R. Rosen, Effects of Zeaxanthin on Growth and Invasion of Human Uveal Melanoma in Nude Mouse Model., J. Ophthalmol. 2015 (2015) 392305. doi:10.1155/2015/392305.

[22] D.I. Thurnham, A.N. Howard, Studies on meso-zeaxanthin for potential toxicity and mutagenicity, 59 (2013) 455-463. doi:10.1016/j.fct.2013.06.002.

[23] S.R. Kumar, M. Hosokawa, K. Miyashita, Fucoxanthin: a marine carotenoid exerting anti-cancer effects by affecting multiple mechanisms., Mar. Drugs. 11 (2013) 5130-47. doi:10.3390/md11125130.

[24] Guiry MD, M.D. Guiry in Guiry, M.D. \& Guiry, G.M. 2017. AlgaeBase. World-wide electronic publication, National University of Ireland, Galway., (2017). http://www.algaebase.org (accessed March 7, 2017).

[25] S. Roy, C. Llewellyn, E.S. Egeland, G. Johnsen, eds., Phytoplankton Pigments Characterization, Chemotaxonomy and Applications in Oceanography | Oceanography and marine science | Cambridge University Press, Cambridge University Press, 2011. http://www.cambridge.org/us/academic/subjects/earth-and-environmentalscience/oceanography-and-marine-science/phytoplankton-pigments-characterizationchemotaxonomy-and-applications-oceanography (accessed October 14, 2014).

[26] E. Destandau, T. Michel, C. Elfakir, Microwave-assisted extraction, in: M.A. Rostagno, J.M. Prado (Eds.), Nat. Prod. Extr. Princ. Appl., 2013: pp. 157-195. https://www.google.fr/search?q=microwave+assisted+extraction+industrial\&oq=micro wave+assisted+extraction+industrial \&aqs=chrome...69i57.12099j0j8\&sourceid=chrom 
e\&es_sm=93\&ie=UTF-8\#q=microwave+assisted+extraction+industrial (accessed May 19, 2014).

[27] R.R.L. Guillard, P.E. Hargraves, Stichochrysis immobilis is a diatom, not a chrysophyte, Phycologia. 32 (1993) 234-236. doi:10.2216/i0031-8884-32-3-234.1.

[28] V. Pasquet, J.-R. Chérouvrier, F. Farhat, V. Thiéry, J.-M. Piot, J.-B. Bérard, R. Kaas, B. Serive, T. Patrice, J.-P. Cadoret, L. Picot, Study on the microalgal pigments extraction process: Performance of microwave assisted extraction, Process Biochem. 46 (2011) 59-67. doi:10.1016/j.procbio.2010.07.009.

[29] C. Juin, J.-R. Chérouvrier, V. Thiéry, A.-L. Gagez, J.-B. Bérard, N. Joguet, R. Kaas, J.P. Cadoret, L. Picot, Microwave-assisted extraction of phycobiliproteins from Porphyridium purpureum., Appl. Biochem. Biotechnol. 175 (2015) 1-15. doi:10.1007/s12010-014-1250-2.

[30] C. Juin, A. Bonnet, E. Nicolau, J.-B. Bérard, R. Devillers, V. Thiéry, J.-P. Cadoret, L. Picot, UPLC-MSE Profiling of Phytoplankton Metabolites: Application to the Identification of Pigments and Structural Analysis of Metabolites in Porphyridium purpureum, Mar. Drugs. 13 (2015) 2541-2558. doi:10.3390/md13042541.

[31] C.P. Satori, M. Ramezani, J.S. Koopmeiners, A.F. Meyer, J.A. Rodriguez-Navarro, M.M. Kuhns, T.H. Taylor, C.L. Haynes, J.J. Dalluge, E.A. Arriaga, Checkpoints for preliminary identification of small molecules found enriched in autophagosomes and activated mast cell secretions analyzed by comparative UPLC/MS ${ }^{\text {e }}$, Anal. Methods. 9 (2017) 46-54. doi:10.1039/C6AY02500E.

[32] P. Tipthara, C. Kunacheva, Y.N.A. Soh, S.C.C. Wong, N.S. Pin, D.C. Stuckey, B.O. Boehm, Global Profiling of Metabolite and Lipid Soluble Microbial Products in 
Anaerobic Wastewater Reactor Supernatant Using UPLC-MS ${ }^{\text {E }}$, J. Proteome Res. 16 (2017) 559-570. doi:10.1021/acs.jproteome.6b00681.

[33] T. Wu, H. Lv, F. Wang, Y. Wang, Characterization of Polyphenols from Lycium ruthenicum Fruit by UPLC-Q-TOF/MS ${ }^{\mathrm{E}}$ and Their Antioxidant Activity in Caco-2 Cells, J. Agric. Food Chem. 64 (2016) 2280-2288. doi:10.1021/acs.jafc.6b00035.

[34] H. Li, Y. Yu, Z. Wang, J. Geng, Y. Dai, W. Xiao, X. Yao, Chemical Profiling of ReDu-Ning Injection by Ultra-Performance Liquid Chromatography Coupled with Electrospray Ionization Tandem Quadrupole Time-of-Flight Mass Spectrometry through the Screening of Diagnostic Ions in MSE Mode, PLoS One. 10 (2015) e0121031. doi:10.1371/journal.pone.0121031.

[35] Y. Lecompte, M. Rosset, C. Richeval, L. Humbert, P. Arpino, UPLC-ESI-Q-TOFMSE identification of urinary metabolites of the emerging sport nutrition supplement methoxyisoflavone in human subjects, J. Pharm. Biomed. Anal. 96 (2014) 127-134. doi:10.1016/j.jpba.2014.03.031.

[36] R. Ronca, E. Di Salle, A. Giacomini, D. Leali, P. Alessi, D. Coltrini, C. Ravelli, S. Matarazzo, D. Ribatti, W. Vermi, M. Presta, Long pentraxin-3 inhibits epithelialMesenchymal transition in melanoma cells, 12 (2013) 2760-2771. doi:10.1158/15357163.MCT-13-0487.

[37] M. Hedidi, W. Erb, G. Bentabed-Ababsa, F. Chevallier, L. Picot, V. Thiéry, S. Bach, S. Ruchaud, T. Roisnel, V. Dorcet, F. Mongin, Synthesis of N-pyridyl azoles using a deprotometalation-iodolysis-N-arylation sequence and evaluation of their antiproliferative activity in melanoma cells, 72 (2016) 6467-6476. doi:10.1016/j.tet.2016.08.056. 
[38] G. Bricheux, D.G. Mahoney, S.P. Gibbs, Development of the pellicle and thecal plates following ecdysis in the dinoflagellateGlenodinium foliaceum, Protoplasma. 168 (1992) 159-171. doi:10.1007/BF01666262.

[39] S. Roy, C. Llewellyn, E. Skartstad Egeland, G. Johnsen, eds., Phytoplankton Pigments: Characterization, Chemotaxonomy and Applications in Oceanography, Cambridge University Press, 2011. http://books.google.com/books?id=K_2AJHmdvxgC\&pgis=1 (accessed September 16, 2013).

[40] R. Matsuoka, K. Awai, Y. Shioi, Pigment composition and pigment-protein complex from Symbiodinium sp. strain Y106, 6A Cell Mol. Biol. Symbiosis. (2012) 9-13.

[41] T. Aakermann, S. Liaaen-Jensen, Pyrrhoxanthin, reisolation and absolute configuration, Phytochemistry. 31 (1992) 1779-1782. doi:10.1016/00319422(92)83146-P.

[42] T. Wakahama, H. Okuyama, T. Maoka, S. Takaichi, Unique carotenoid lactoside, P457, in Symbiodinium sp. of dinoflagellate, 59 (2012) 155-157.

[43] T. Wakahama, A. Laza-Martínez, A.I. Bin Haji Mohd Taha, H. Okuyama, K. Yoshida, K. Kogame, K. Awai, M. Kawachi, T. Maoka, S. Takaichi, Structural Confirmation of a Unique Carotenoid Lactoside, P457, in Symbiodinium sp. Strain nbrc 104787 Isolated from a Sea Anemone and its Distribution in Dinoflagellates and Various Marine Organisms, 48 (2012) 1392-1402. doi:10.1111/j.1529-8817.2012.01219.x.

[44] J. Jiang, H. Zhang, G.S. Orf, Y. Lu, W. Xu, L.B. Harrington, H. Liu, C.S. Lo, R.E. Blankenship, Evidence of functional trimeric chlorophyll a/c2-peridinin proteins in the dinoflagellate Symbiodinium, 1837 (2014) 1904-1912. doi:10.1016/j.bbabio.2014.07.023. 
[45] J.E. Johansen, W.A. Svec, S. Liaaen-Jensen, F.T. Haxo, Carotenoids of the dinophyceae, Phytochemistry. 13 (1974) 2261-2271. doi:10.1016/00319422(74)85038-7.

[46] A. Davies, A. Khare, A. Mallams, R. Massy-Westropp, G. Moss, B. Weedon, Carotenoids and Related Compounds. Part 38.' Synthesis of (3RS,3'RS)- Alloxanthin and Other Acetylenes, J. Chem.Soc., Perkin Trans. 1 (1984) 2147-57.

[47] R.-X. Yu, X.-M. Hu, S.-Q. Xu, Z.-J. Jiang, W. Yang, Effects of fucoxanthin on proliferation and apoptosis in human gastric adenocarcinoma MGC-803 cells via JAK/STAT signal pathway., Eur. J. Pharmacol. 657 (2011) 10-9. doi:10.1016/j.ejphar.2010.12.006.

\section{Acknowledgments}

This research was financially supported by the French cancer league (Comité 17 de la Ligue Nationale contre le Cancer). We thank the IFREMER PHYC lab (Nantes, France) for the generous gift of the $H t$ strain and the "Cancéropôle Grand Ouest, axe Valorisation des produits de la mer en cancérologie" for scientific support.

\section{Authors' contribution and responsibility}

JBB produced $H t$ biomass. QH, JG and AF performed the extraction, purification and cell culture experiments. QH, $\mathrm{AB}$ and $\mathrm{JG}$ performed the HRMS analysis. $\mathrm{QH}$ and $\mathrm{NJ}$ performed the SEM experiment. VT and LP designed the experiments, interpreted the data and directed the study. LP wrote and corrected the manuscript and takes responsibility for the integrity of the work, from inception to finished article. 


\section{Competing interests}

The authors declare they have no competing interests.

\section{Graphical abstract}




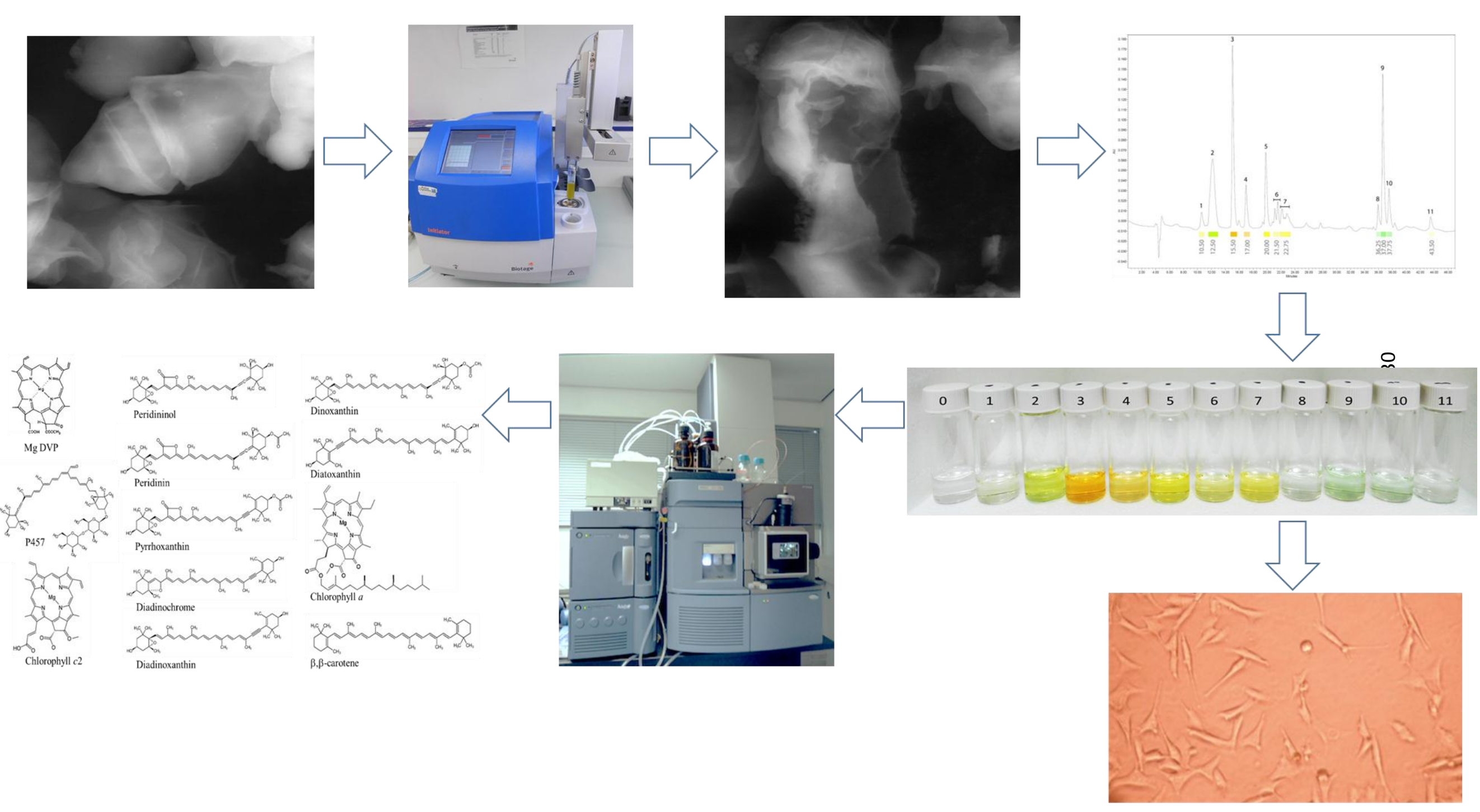


Supplementary data 1. Structure of parent and fragment ions detected by UPLC-MS ${ }^{\mathrm{E}}$ analysis of $\mathrm{Ht}$ pigments. Mass spectra and fragmentation profiles of $\beta$, $\beta$-carotene, chlorophyll $a$, chlorophyll c2, diatoxanthin, diadinoxanthin/diadinochrome, pheophytin $a$, peridinin and peridinin isomer are presented in [30].

\section{Diatoxanthin}

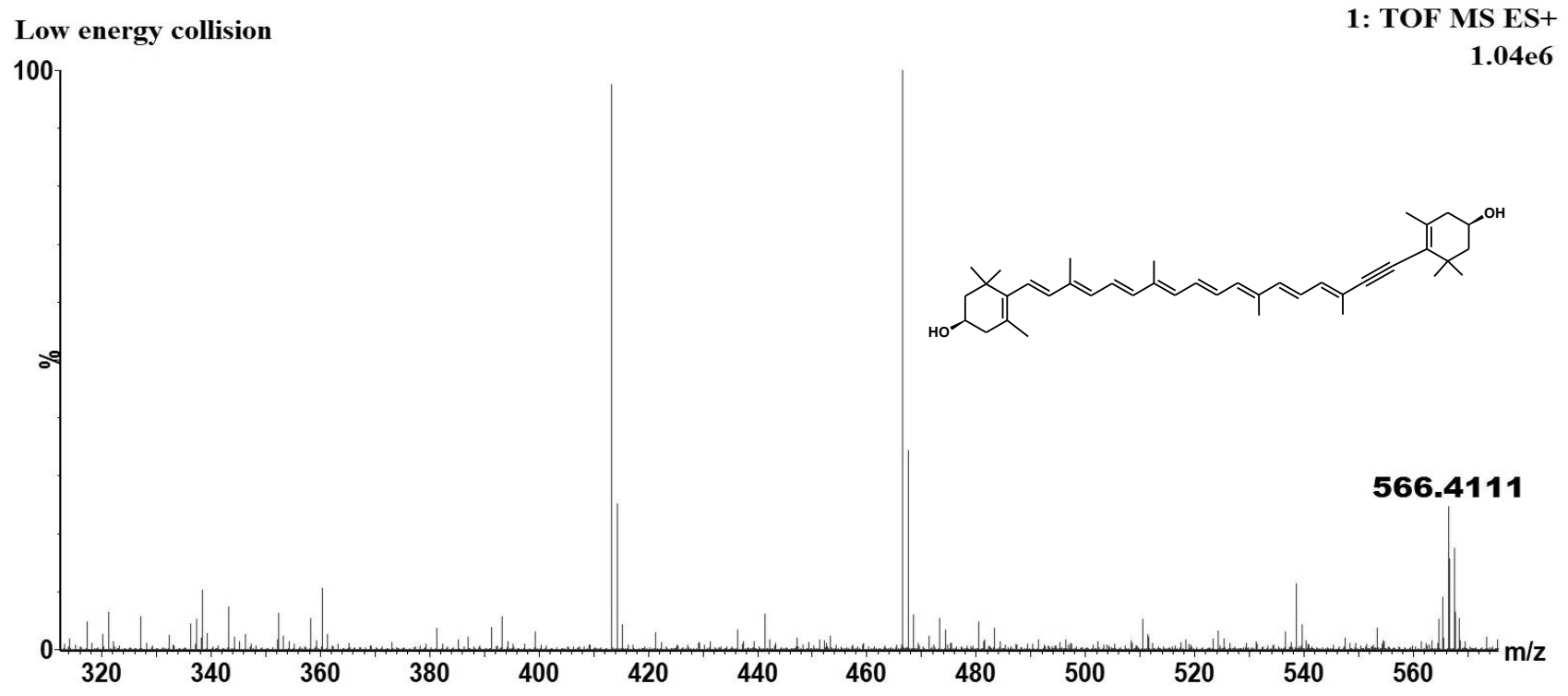




\section{$\underline{\text { Dinoxanthin }}$}

Low energy collision

1: TOF MS ES+

100

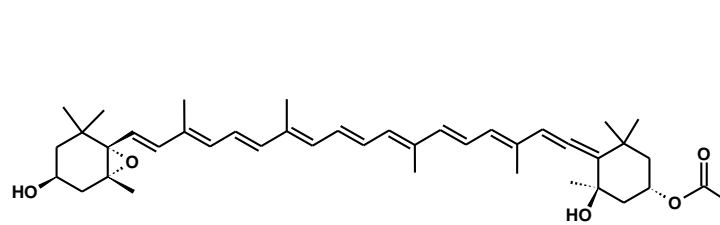

$1.12 \mathrm{e} 6$
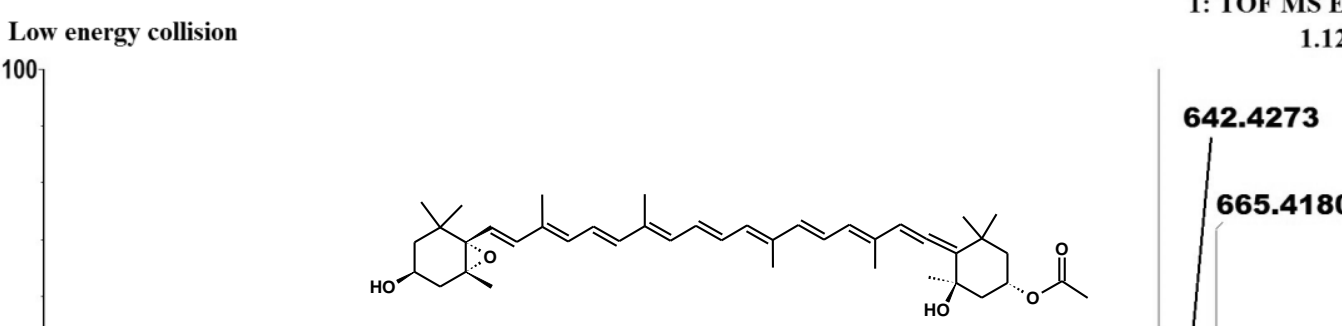

우
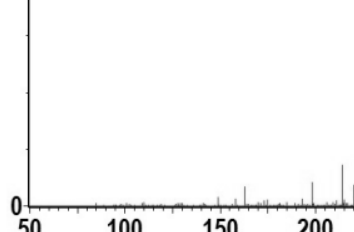

$250 \quad 300$
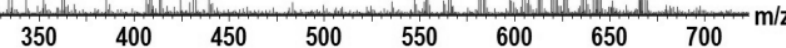

High energy collision

2: TOF MS ES+

100 665.4182 4.45e6

665.4180

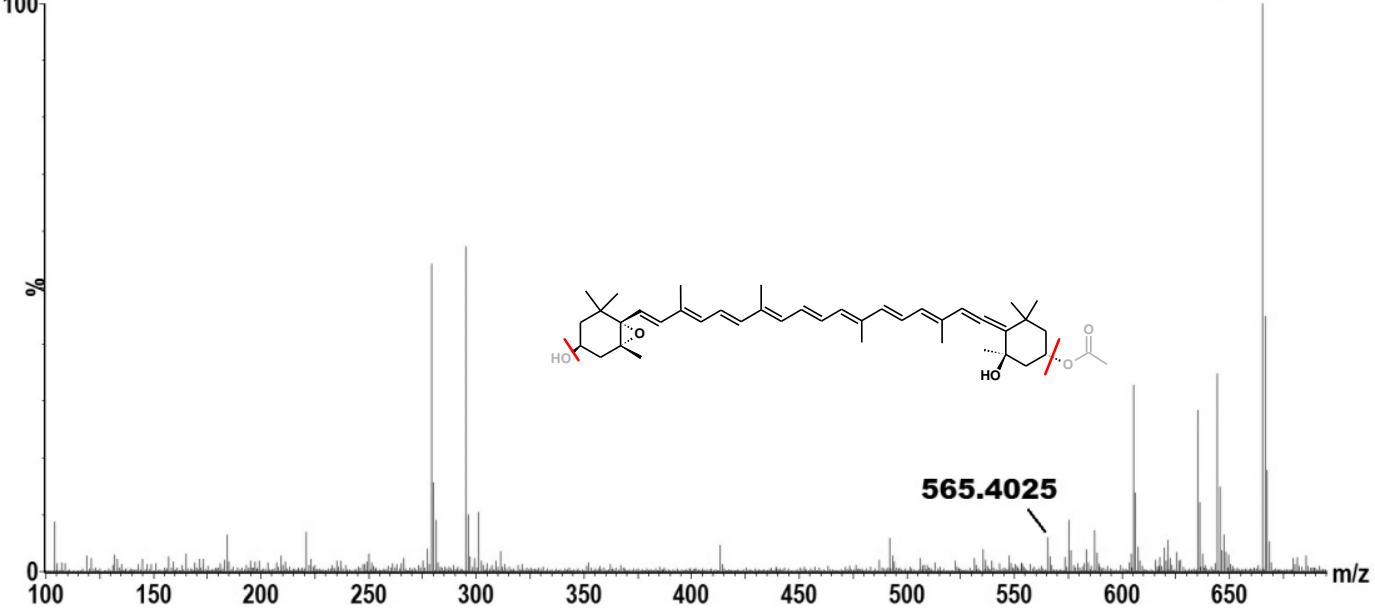




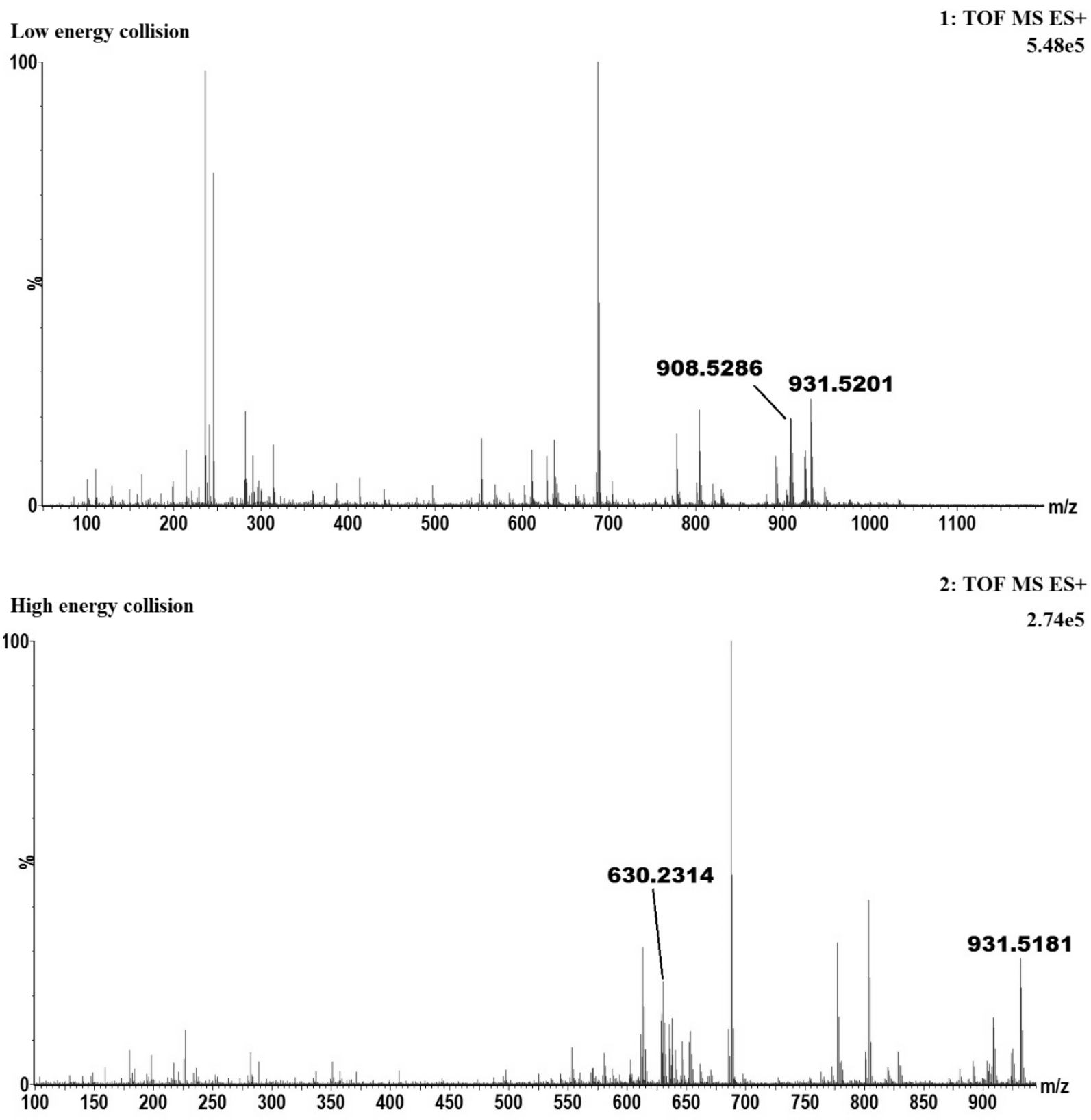




\section{P457}
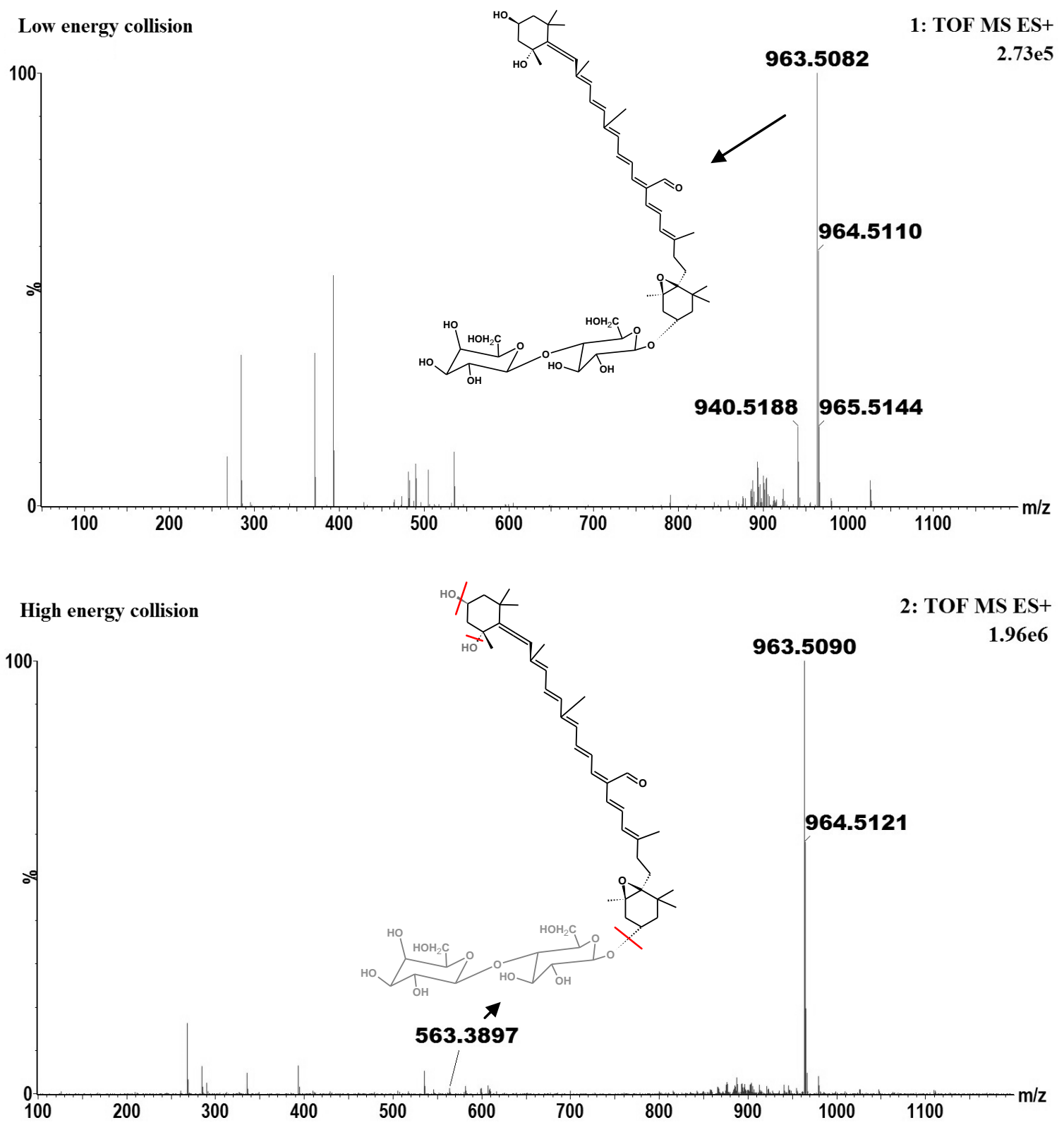


\section{Peridininol}

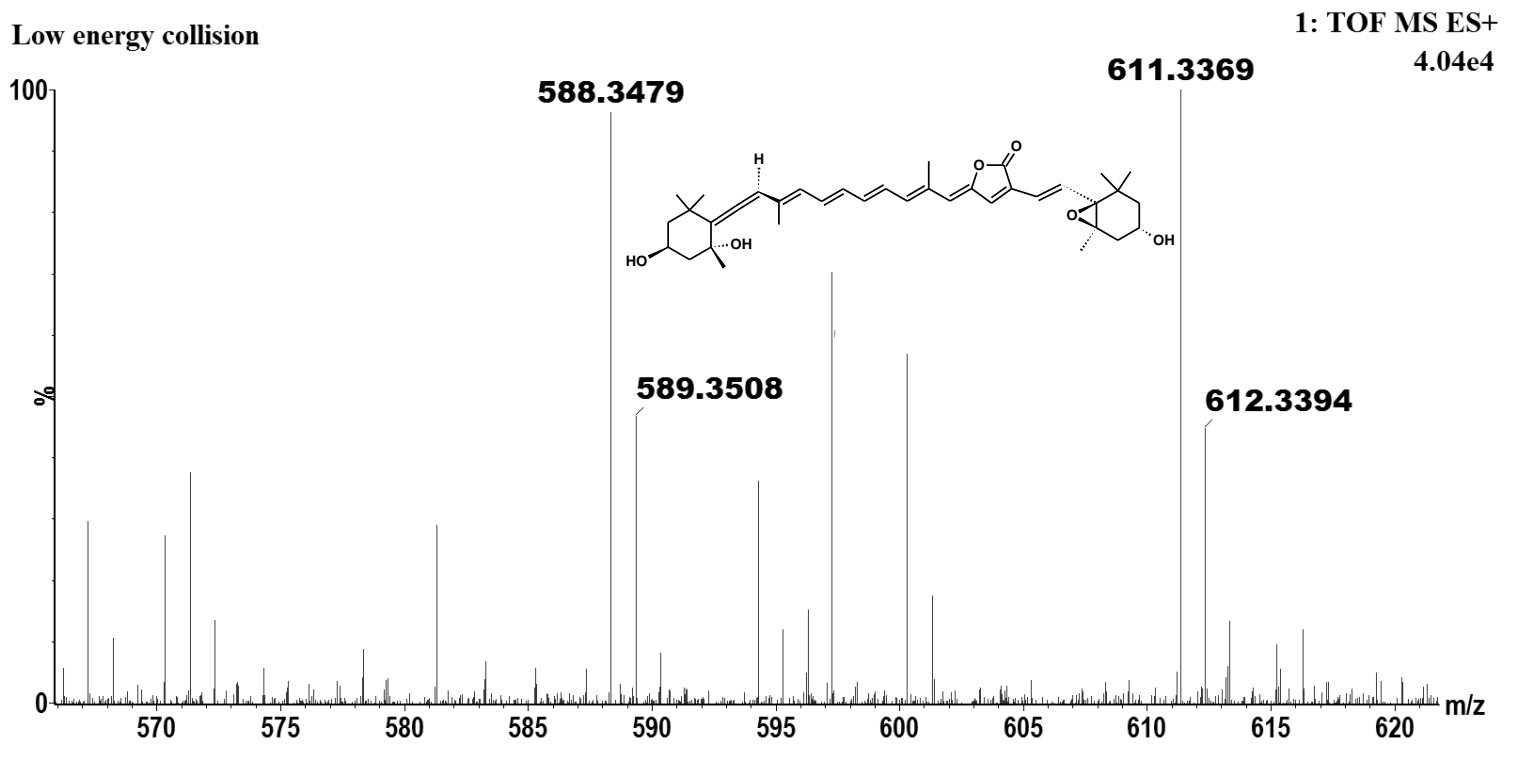




\section{Pyrrhoxanthin}

9.88e5

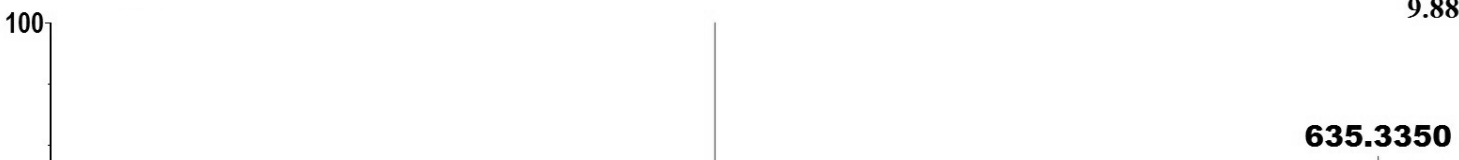

$100 \quad 150$

High energy collision

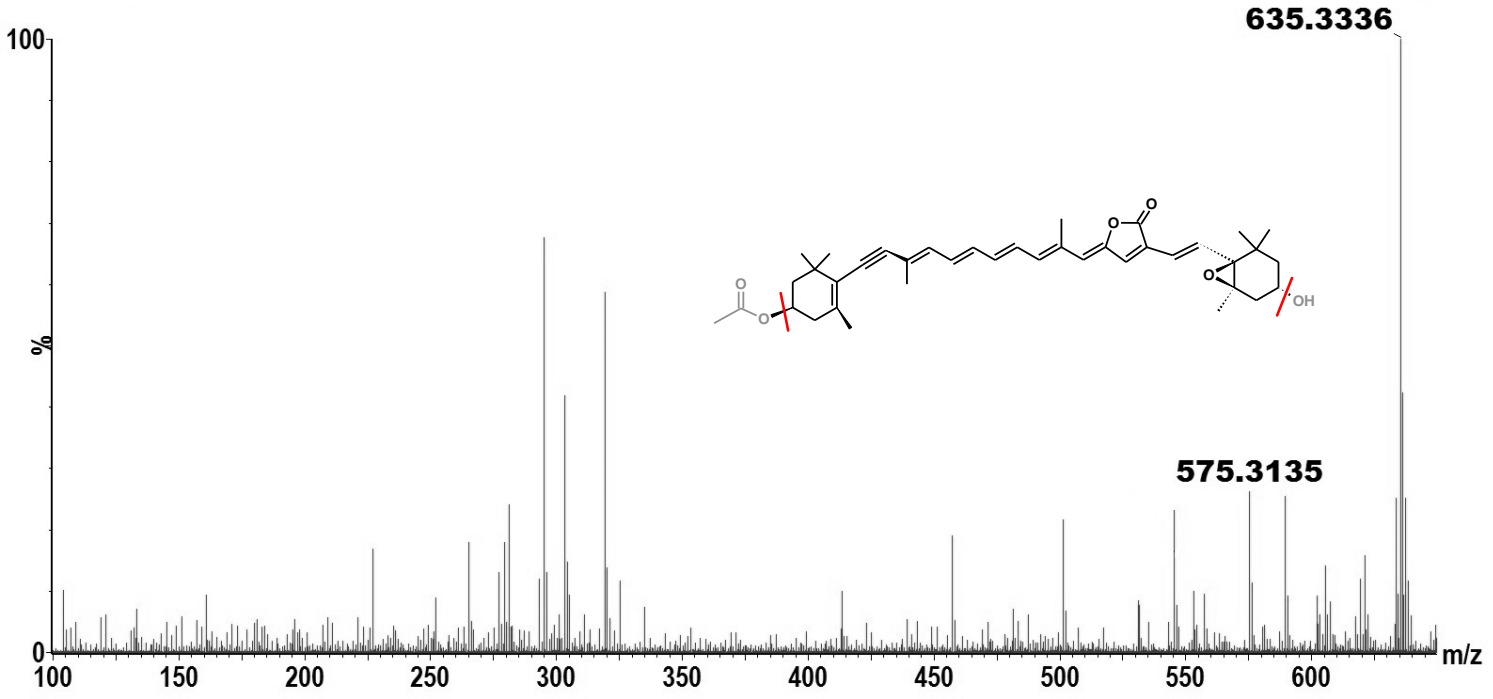

